Research article

Open Access

\title{
Membrane estrogen receptor- $\alpha$ levels predict estrogen-induced ERK1/2 activation in MCF-7 cells
}

\author{
Dragoslava Zivadinovic and Cheryl S Watson
}

\author{
Department of Human Biological Chemistry and Genetics, University of Texas Medical Branch, Galveston, Texas, USA \\ Corresponding author: Cheryl S Watson, cswatson@utmb.edu
}

Received: 16 Apr 2004 Revisions requested: 12 Jul 2004 Revisions received: 18 Aug 2004 Accepted: 7 Oct 2004 Published: 26 Nov 2004

Breast Cancer Res 2005, 7:R130-R144 (DOI 10.1186/bcr959)

(C) 2004 Zivadinovic and Watson, licensee BioMed Central Ltd.

This is an Open Access article distributed under the terms of the Creative Commons Attribution License (http://creativecommons.org/licenses/by/ 2.0), which permits unrestricted use, distribution, and reproduction in any medium, provided the original work is cited.

\begin{abstract}
Introduction We examined the participation of a membrane form of estrogen receptor (mER)- $\alpha$ in the activation of mitogenactivated protein kinases (extracellular signal-regulated kinase [ERK]1 and ERK2) related to cell growth responses in MCF-7 cells.

Methods We immunopanned and subsequently separated MCF-7 cells (using fluorescence-activated cell sorting) into $m E R-\alpha$-enriched (mERhigh) and mER- $\alpha$-depleted (mERlow) populations. We then measured the expression levels of mER- $\alpha$ on the surface of these separated cell populations by immunocytochemical analysis and by a quantitative 96 -well plate immunoassay that distinguished between mER- $\alpha$ and intracellular ER- $\alpha$. Western analysis was used to determine colocalized estrogen receptor (ER)- $\alpha$ and caveolins in membrane subfractions. The levels of activated ERK1 and ERK2 were determined using a fixed cell-based enzyme-linked immunosorbent assay developed in our laboratory.

Results Immunocytochemical studies revealed punctate ER- $\alpha$ antibody staining of the surface of nonpermeabilized $m E R^{\text {high }}$ cells, whereas the majority of mER low cells exhibited little or no staining. Western analysis demonstrated that $m E R^{\text {high }}$ cells expressed caveolin-1 and caveolin-2, and that ER- $\alpha$ was

contained in the same gradient-separated membrane fractions. The quantitative immunoassay for ER- $\alpha$ detected a significant difference in $\mathrm{mER}-\alpha$ levels between $\mathrm{mER}{ }^{\text {high }}$ and $m E R^{\text {low }}$ cells when cells were grown at a sufficiently low cell density, but equivalent levels of total ER- $\alpha$ (membrane plus intracellular receptors). These two separated cell subpopulations also exhibited different kinetics of ERK $1 / 2$ activation with $1 \mathrm{pmol} / \mathrm{l}$ $17 \beta$-estradiol $\left(E_{2}\right)$, as well as different patterns of $E_{2}$ dosedependent responsiveness. The maximal kinase activation was achieved after 10 min versus 6 min in $m E R^{\text {high }}$ versus $m E R^{\text {low }}$ cells, respectively. After a decline in the level of phosphorylated ERKs, a reactivation was seen at $60 \mathrm{~min}$ in $\mathrm{mER}{ }^{\text {high }}$ cells but not in mERlow cells. Both $1 \mathrm{~A}$ and $2 \mathrm{~B}$ protein phosphatases participated in dephosphorylation of ERKs, as demonstrated by efficient reversal of ERK $1 / 2$ inactivation with okadaic acid and cyclosporin A.

Conclusion Our results suggest that the levels of mER- $\alpha$ play a role in the temporal coordination of phosphorylation/ dephosphorylation events for the ERKs in breast cancer cells, and that these signaling differences can be correlated to previously demonstrated differences in $E_{2}$-induced cell proliferation outcomes in these cell types.
\end{abstract}

Keywords: membrane estrogen receptor- $\alpha$, MCF-7 human breast cancer cells, extracellular regulated protein kinase

\section{Introduction}

Estrogen receptor (ER)- $\alpha$ has traditionally been defined as a ligand-dependent transcription factor that regulates its target genes by binding to estrogen response elements present in the promoters of many responsive genes [1]. However, an ever-increasing number of reports indicate that the cellular actions of estrogens can be initiated at the plasma membrane, through membrane versions of estrogen receptors (mERs) [2-4] or via other membrane-resident $17 \beta$-estradiol $\left(E_{2}\right)$-binding proteins [5]. There is also evidence that mER- $\alpha$ from vascular endothelium and human MCF-7 breast cancer cells is localized in specialized cholesterol-rich membrane microstructures (caveolae), where it can associate with different signaling

$\mathrm{CV}=$ crystal violet; $\mathrm{DCSS}=$ medium with $4 \times$ dextran-coated charcoal-stripped serum; $\mathrm{E}_{2}=17 \beta$-estradiol; EGF = epidermal growth factor; $\mathrm{ER}=$ estrogen receptor; ERK = extracellular signal-regulated kinase; $F A C S=$ fluorescence-activated cell sorting; $O A=$ okadaic acid; $M A P K=$ mitogenactivated protein kinase; $M E K=$ mitogen-activated protein kinase kinase; $m E R=$ membrane estrogen receptor; $p N p=p a r a n i t r o p h e n o l ; P P=p r o t e i n$ phosphatase; $\mathrm{tER}=$ total estrogen receptor. 
molecules and participate in various nongenomic actions $[6,7]$.

$A$ variety of rapid $E_{2}$-induced signal transduction events can lead to stimulation of calcium flux, cAMP production, phospholipase $\mathrm{C}$ activation, and inositol phosphate production [8]. Mitogen-activated protein kinases (MAPKs) such as extracellular signal-regulated kinase (ERK) 1 and ERK2 are also rapidly stimulated by estrogens in various cell types (e.g. endothelial [9], osteoblastic [10], neuroblastoma [11], and breast cancer cells [12]). However, the specific relationship of these responses to the levels of antibody-identified ER- $\alpha$ in the membrane has rarely been investigated [13,14]; other rapid estrogen-induced actions were specifically linked to $\mathrm{mER}-\alpha$ in pituitary tumor cells in our previous studies [15-18].

The two isoforms of ERK ( $p 42$ and p44) play critical roles in the control of cell proliferation, differentiation, homeostasis, and survival. Traditionally, autophosphorylation of receptor tyrosine kinases after ligand binding initiates the cascade of phosphorylation steps that result in dual ERK phosphorylation (on Thr202 and Tyr204 in the human enzyme, or Thr183 and Tyr185 in the rat enzyme [19]). The signaling pathway initiated by $\mathrm{E}_{2}$ at the level of the plasma membrane is not yet completely understood, although recent studies have implicated a cascade of intermediary proteins and signaling steps involving $m E R-\alpha, G$-proteins, Src-induced matrix metalloproteinases that liberate heparin-binding epidermal growth factor (EGF), and EGF receptor [13]; the involvement of many other signaling pathways remains unexamined.

Whether different levels of mER can influence signaling parameters (such as kinetics and final levels of second messengers) that lead to physiological responses remains to be investigated. To address this question we separated MCF-7 cells into two subpopulations based on outer membrane-exposed mER- $\alpha$ levels and confirmed their differential mER- $\alpha$ expression by several methods. We investigated the association of mER- $\alpha$ with caveolin-rich membrane fractions in cells enriched for membrane display of these receptors. We then linked the level of mER- $\alpha$ to the magnitude and patterns of $E_{2}$-induced ERK1/2 activation. Although activation of kinases was previously demonstrated, those other studies did not address the accompanying inactivation mechanisms for ERKs involving several specific cellular phosphatases.

\section{Methods}

\section{Cell immunoseparation and subculturing}

Our MCF-7 cells originated from the Michigan Cancer Center. We separated them into two subpopulations by immunopanning $[16,20]$ using C-542 carboxyl-terminal ER$\alpha$ antibody provided by Drs Dean Edwards and Nancy
Weigel; this antibody is now commercially available from Stressgen Biotechnologies (Victoria, Canada). Briefly, sterile antibody on the surface of a petri plate bound cells over a 1 -hour time period at $4^{\circ} \mathrm{C}$, and cells that attached to the plate $\left(m E R^{+}\right)$were propagated separately from those that did not bind (mERlow). The $m E R^{+}$cells were then subjected to further selection via fluorescence-activated cell sorting (FACS) using the same antibody [21]. Cells undergoing sequential separation were highly enriched for mER- $\alpha$ (mER high). All cell subpopulations were routinely cultured in phenol-red free Dulbecco's modified eagle medium (Gibco-BRL, Grand Island, NY, USA) supplemented with 10\% heat-inactivated DSCS (defined/supplemented bovine calf serum; HyClone Laboratories Inc., Logan, UT, USA) and $1 \%$ of an antibiotic-antimycotic (Gibco Invitrogen Corporation, \#15240-062). Cells used in the experiments were between passage 8 and 14 after separation.

Three days before each experiment, the cell growth medium was replaced with medium containing $4 \times$ dextrancoated charcoal stripped serum (DCSS medium) or completely defined medium (DM; phenol-red free Dulbecco's modified eagle medium with $5 \mu \mathrm{g} / \mathrm{ml}$ each of insulin and transferrin, $5 \mathrm{ng} / \mathrm{ml}$ selenium, and $0.1 \%$ bovine serum albu$\mathrm{min})$. Stripped serum was produced by incubation with an equivalent volume of packed $0.25 \%$ weight/vol charcoal Norit A for 2 hours on a shaker at $4^{\circ} \mathrm{C}$. The charcoal preparation had previously been suspended in $0.0025 \%$ (weight/vol) dextran T-70 (Sigma-Aldrich, St. Louis, MO, USA) in $0.25 \mathrm{~mol} / \mathrm{l}$ sucrose, $1.5 \mathrm{mmol} / \mathrm{l} \mathrm{MgCl}_{2}$, and 10 $\mathrm{mmol} / \mathrm{l} \mathrm{HEPES}$ ( $\mathrm{pH}$ 7.6). The charcoal was pelleted at 500 $g$ for $10 \mathrm{~min}$, the supernatant (stripped serum) decanted, and the process repeated a total of four times.

\section{Fluorescence immunocytochemical detection of membrane ER- $\alpha$}

The protocol published for immunocytohcemical detection of $m E R-\alpha$ in the $\mathrm{GH}_{3}$ rat pituitary cell line [22] was optimized for MCF-7 cells. Briefly, the cells were fixed in $2 \%$ paraformaldehyde $/ 0.1 \%$ glutaraldehyde in phosphate-buffered saline for $25 \mathrm{~min}$ at room temperature; those conditions preserve the integrity of the cell membrane and enable detection of the specific ER- $\alpha$ antibody bound to the cell surface without interference from the usually more intense nuclear signal. Autofluorescence was reduced by blocking the aldehyde groups for $15 \mathrm{~min}$ with $1 \%$ $\mathrm{Na}_{2} \mathrm{HPO}_{4}$ and $0.05 \% \mathrm{NaBH}_{4}$. Nonspecific binding sites were blocked with $0.1 \%$ fish gelatin in phosphate-buffered saline for $\mathbf{4 5} \mathrm{min}$ at room temperature, which we successfully used previously in GH6/B6/F10 cells [23,24]. For the present studies with MCF-7 cells, we compared the nonspecific antibody signal blocking abilities of fish gelatin, horse serum, bovine serum albumin and nonfat dry milk, all commonly used methods, and found them to be equally useful. 
The plates were incubated with C-542 antibody $(5-10 \mu \mathrm{g} /$ $\mathrm{ml}$ ) overnight at $4^{\circ} \mathrm{C}$ in the blocking solution. To detect the bound primary antibody and amplify the signal, we used a biotinylated secondary antibody from the biotin/avidin Vectastain ABC-Alkaline Phosphatase kit and Vector red as a substrate, together with $40 \mu \mathrm{l}$ of $125 \mathrm{mmol} / \mathrm{l}$ levamisol (which inhibits the endogenous alkaline phosphatases). All the components for detection of bound primary antibody were obtained from Vector Laboratories Inc. (Burlingame, CA, USA). Fluorescence photography was performed as previously described $[15,22]$. The images were photographed with Kodak $\mathrm{HC} 4000$ color film and a camera (Model C-35AD-4) with Olympus AHBT microscope and fluorescence attachment (model AH2-RFL) using the FITC filter, under $100 \times$ magnification. Digital deconvolution and pseudo-coloring were performed with Image-Pro Plus software applied to images captured through the FITC filter with a CoolSNAP-Pro digital monochrome camera and a ProScan motorized stage (Meyer Instruments, Houston, TX, USA) attached to a Olympus AHBT microscope equipped with fluorescence attachments (model $\mathrm{AH} 2$ $\mathrm{RFL}$ ).

\section{Quantification of membrane ER- $\alpha$}

The $\mathrm{mER}$ was quantified with a protocol modified from one previously developed in our laboratory for $\mathrm{GH}_{3}$ cells [23]. Briefly, cells plated and treated in 96-well plates were fixed as described for immunocytochemistry (see above), and the integrity of the membrane was verified by lack of staining with the anti-clathrin antibody (ICN Biomedicals, Aurora, $\mathrm{OH}, \mathrm{USA}$ ), as clathrin is localized just inside the plasma membrane. Different concentrations of C-542 ER$\alpha$ antibody were tested (in the range $1-12 \mu \mathrm{g} / \mathrm{ml}$ ), and the tagging enzymatic reaction (alkaline phosphatase) was monitored for different time intervals $(5,15$ and $30 \mathrm{~min}$ ) in order to determine optimal conditions for measurement. The specificity of the C-542 antibody was checked by comparing its binding with the nonspecific binding of mouse $\operatorname{lgG}_{1 \mathrm{k}}\left(\mathrm{mlgG}_{1 \mathrm{k}}\right.$, of the same immunoglobulin isotype) and by the ability of the peptide representing the $\mathrm{C}-542$ epitope (Genosys, Woodlands, TX, USA) to decrease C-542 binding. Other controls included incubation without any antibody to detect endogenous phosphatase not inhibited by levamisol, and without primary antibody to detect nonspecific binding of secondary antibody. The total cellular ER- $\alpha$ was measured by applying the same procedure to cells permeabilized by including $0.1 \%$ of the non-ionic detergent IGEPAL CA-630 (Sigma-Aldrich) during the fixation procedure. The absorbance of the alkaline phosphatase product paranitrophenol ( $\mathrm{pNp}$ ) in each well was measured at 405 $\mathrm{nm}$ and normalized against the number of cells determined by the absorbance of crystal violet (CV) at $590 \mathrm{~nm}$, as previously described [23].

\section{Caveolae preparation and Western analysis}

To concentrate caveolin-rich membranes, we extended a previously published protocol [25] by introducing a dialysis step to remove sucrose, and a vacuum spin at a low drying rate to concentrate the samples. Specifically, cells were seeded in three $150 \mathrm{~mm}$ diameter plates and grown in serum-supplemented medium until $60 \%$ confluent. The growth medium was replaced with DCSS medium devoid of antimycotic compound and cultured for an additional 3 days. Cells from all three plates were collected in $1 \mathrm{ml}$ lysis buffer consisting of $50 \mathrm{mmol} / \mathrm{I} \mathrm{Tris} / \mathrm{HCl}(\mathrm{pH} 7.5), 5 \mathrm{mmol} / \mathrm{l}$ EDTA, $100 \mathrm{nmol} / \mathrm{l} \mathrm{NaCl}, 50 \mathrm{mmol} / \mathrm{l} \mathrm{NaF}, 1 \mathrm{mmol} / \mathrm{l} \mathrm{PMSF}$, $0.2 \%$ TritonX-100 and protease inhibitor cocktail P8340 (100 × diluted; Sigma-Aldrich). Cells in solution were passed through a 25-g syringe needle, then homogenized with 25 strokes using a Dounce B-type pestle. The homogenate was adjusted to $45 \%$ sucrose by addition of an equivalent volume of $90 \%$ sucrose. A discontinuous sucrose gradient consisting of the sample, 35\% sucrose, and a top layer of $5 \%$ sucrose was centrifuged for 18 hours at $200,000 \mathrm{~g}$. Fractions of $1 \mathrm{ml}$ were collected and checked for the presence of caveolin- 1 and caveolin-2 by Western analysis using antibodies from Biosciences (San Jose, CA, USA). Fractions 5 and 6 (the interface between $5 \%$ and $35 \%$ sucrose) contained the highest amount of caveolin-1. Those two fractions were pooled and dialyzed overnight against the lysis buffer. The sample was then concentrated by vacuum spin, and $20 \mu \mathrm{g}$ of these proteins separated by $4-20 \%$ SDS-PAGE. The proteins were transferred to nitrocellulose membranes and the mER- $\alpha$ bands were probed with C-542 ER- $\alpha$ antibody. After incubation with secondary antibody (conjugated with horse radish peroxidase) the bands were visualized with an ECL kit (Amersham Pharmacia Biotech, Piscataway, NJ, USA).

\section{Fixed cell-based enzyme-linked immunosorbent assay detection of activated ERK1/2 in 96-well plates}

A protocol previously developed in our laboratory for other cells [26] was optimized for MCF-7 cells. Cells were plated at a density of $4000 /$ well in 96 -well plates, and after 24 hours the growth medium was replaced with DCSS medium. After 3 more days of culture the cells were treated with $E_{2}(1 \mathrm{pmol} / \mathrm{l})$ for different time intervals $(3,6,10,20$, 30 and $60 \mathrm{~min}$ ), or with different $\mathrm{E}_{2}$ concentrations (from $10^{-16}$ to $10^{-7} \mathrm{~mol} / \mathrm{l}$ ) for 10 and $6 \mathrm{~min}$ for $\mathrm{mER}{ }^{\text {high }}$ and $\mathrm{mER}$ low cells, respectively. After treatments the cells were fixed in $2 \%$ paraphormaldehyde $/ 0.21 \%$ picric acid for 2 days at $4^{\circ} \mathrm{C}$. The cells were subjected to a 60 min blocking step with $0.1 \%$ fish gelatin and $0.1 \%$ Triton $\mathrm{X}-100$ at room temperature. Incubation with the antibody raised against the phosphorylated forms of ERK1/2 (Cell Signaling Technology, Beverly, MA, USA) was performed overnight at $4^{\circ} \mathrm{C}$ (1:400 dilution). To quantify active ERKs, biotinylated secondary antibody (anti-mouse/anti-rabbit) conjugated to alkaline phosphatase was applied. Substrate $\mathrm{pNp}$ 
phosphate was added and incubated for $25 \mathrm{~min}$ at $37^{\circ} \mathrm{C}$, and the absorbance of the pNp product was determined at $405 \mathrm{~nm}$ in a plate reader (Wallac 1420; Perkin Elmer, Boston, MA, USA). The levels of phosphorylate (pERK1/2) were normalized to the cell number in each well (measured using the CV assay).

To confirm the activation of ERK $1 / 2$ (after 3, 6 and $10 \mathrm{~min}$ in $\mathrm{mER} \mathrm{R}^{\text {high }}$ or $6 \mathrm{~min}$ in $\mathrm{mER}$ low), we pretreated the cells for $15 \mathrm{~min}$ with $40 \mu \mathrm{mol} / \mathrm{l}$ U0126 MEK1/2 inhibitor (Cell Signaling Technology). The ER antagonist ICl182,780 (Tocris Cookson Inc., Ellisville, MO, USA) at a concentration of 1 $\mu \mathrm{mol} / \mathrm{l}$ was tested with or without $\mathrm{E}_{2}$ by preincubating the cells with ICl182,780 for 30 min followed by the addition of $1 \mathrm{pmol} / / \mathrm{E}_{2}$ or by simultaneous addition of ICl182,780 and $E_{2}$. MDA-MB-231 cells used to test the requirement of ER- $\alpha$ for these responses were obtained from ATCC (Manassas, VA, USA). We confirmed the absence of ER- $\alpha$ mRNA in these cells by multiple reverse transcription polymerase chain reaction primer pairs representing the ER- $\alpha$ sequence (data not shown).

\section{Cell proliferation}

Cells were plated at a density of 1000 cells/well in 96-well plates. The next day the growth medium was replaced with DCSS containing different treatments. The $1 \mathrm{pmol} / / \mathrm{E}_{2}$ was present either for the duration of the experiment or as a short pulse treatment $(10 \mathrm{~min})$, whereas $1 \mathrm{pmol} / / \mathrm{E}_{2}$-peroxidase (Sigma-Aldrich; concentration based on the $\mathrm{E}_{2}$ content of the conjugate) was used only as short pulse treatment. The effect of MEK inhibitor ( $40 \mu \mathrm{mol} / / \mathrm{U} 0126)$ on the pulsed $\mathrm{E}_{2}$-induced proliferation of $\mathrm{mER}$ high cells was tested by a pretreatment for $15 \mathrm{~min}$ and an additional treatment for 10 min with $E_{2}$ together with the inhibitor. To block the effect of $E_{2}$ in the pulse treatment, we used ER- $\alpha$ antibody (AER315; NeoMarkers Inc., Fremont, CA, USA) raised against the ligand-binding domain. The cells were pretreated with $1 \mu \mathrm{g} / \mathrm{ml}$ AER315 antibody for 1 hour at room temperature, followed by a $10 \mathrm{~min}$ incubation at $37^{\circ} \mathrm{C}$ with $1 \mathrm{pmol} / / \mathrm{E}_{2}$ in the presence of the antibody. Controls for $E_{2}$ treatment were done on a separate plate, because we previously determined that low amounts of volatilized estrogens can affect responses mediated via nongenomic signaling pathways [24]. After 5 days the cells were fixed with $2 \%$ paraformaldehyde/0.1\% glutaraldehyde in phosphate-buffered saline in preparation for the CV assay (see below).

\section{Crystal violet assay}

The number of the cells in each well was determined with the CV assay [27], which we modified previously [23]. Fixed cells were incubated in $0.1 \%$ filtered $\mathrm{CV}$ solution for $30 \mathrm{~min}$ at room temperature, and excess dye was removed by three brief rinses with $d_{d d} \mathrm{H}_{2} \mathrm{O}$. The plates were then air dried, the dye was extracted with 10\% acetic acid, and the extract (in the same wells) was then read in a plate reader (Wallac 1420, Perkin Elmer) at $590 \mathrm{~nm}$. The utility of this assay was previously verified for GH3B6 cells by comparison with other assays of cell number in combination with the immunoplate assays [23]. In addition, for MCF-7 cells we verified the utility of this assay for measuring cell number by comparison with DNA content measurements and with cell counts by hemocytometer (data not shown). We also compared the CV assay with the MTT assay, which is often used to determine viable cell number (ATCC), and we obtained a linear correlation for the two assays. These latter results are presented in the accompanying paper [28].

\section{Statistical analysis}

Statistical differences between two sets of data were determined using two-way analysis of variance. The differences between the entire curves were tested by comparing the sum of squares of the residuals from each individual curve with the sum of squares of the residuals of the combined curve by applying a Microsoft Excel $\mathrm{F}$ test. $P<0.05$ was considered statistically significant.

\section{Results}

\section{Immunoseparated cell characterization of mER- $\alpha$}

Immunopanning and subsequent FACS successfully separated MCF-7 cells into two populations according to the expression of mER- $\alpha$ observed in immunocytochemistry experiments. Punctate staining can be seen on the surface of unpermeabilized mER ${ }^{\text {high }}$ cells (Fig. 1a), whereas the majority of mER ${ }^{\text {low }}$ cells did not exhibit this staining (Fig. $1 \mathrm{~b})$. Whenever occasional staining was present on cells in the mER low population, its appearance was similar to that seen on $m E R^{\text {high }}$ cells (data not shown). Secondary antibody staining alone was at levels similar to that shown for the mER ${ }^{\text {low }}$ cells in Fig. $1 \mathrm{~b}$ (not shown). When permeabilized, both subpopulations of cells exhibited plentiful cytoplasmic and nuclear staining (not shown) at similar levels. Digital deconvolution (in 15 separate cell planes) performed on a grouping of three unpermeabilized $\mathrm{mER}^{\text {high }}$ cells clearly demonstrated punctuate staining all along the periphery of these cells (Fig. 2).

To determine whether mER- $\alpha$ is in a submembrane location in our mER- $\alpha$-enriched cells, we colocalized mER- $\alpha$ with caveolin proteins in gradient-separated membrane fractions. Our mERhigh cells express both caveolin-1 (form $\alpha$ and $\beta$ represented by doublet bands) and caveolin-2 (Fig. 3a; two different concentrations of protein were loaded in adjacent lanes). In the same density gradient fractions that contained the majority of these caveolar structural proteins (fractions 5 and 6), mER- $\alpha$ was found (Fig. 3b). We detected several prominent bands from both the sucrose gradient fractions (fractions 5 and 6 ) and the whole cell lysates (Fig. 3b, panel 1). To determine those bands whose 
Figure 1
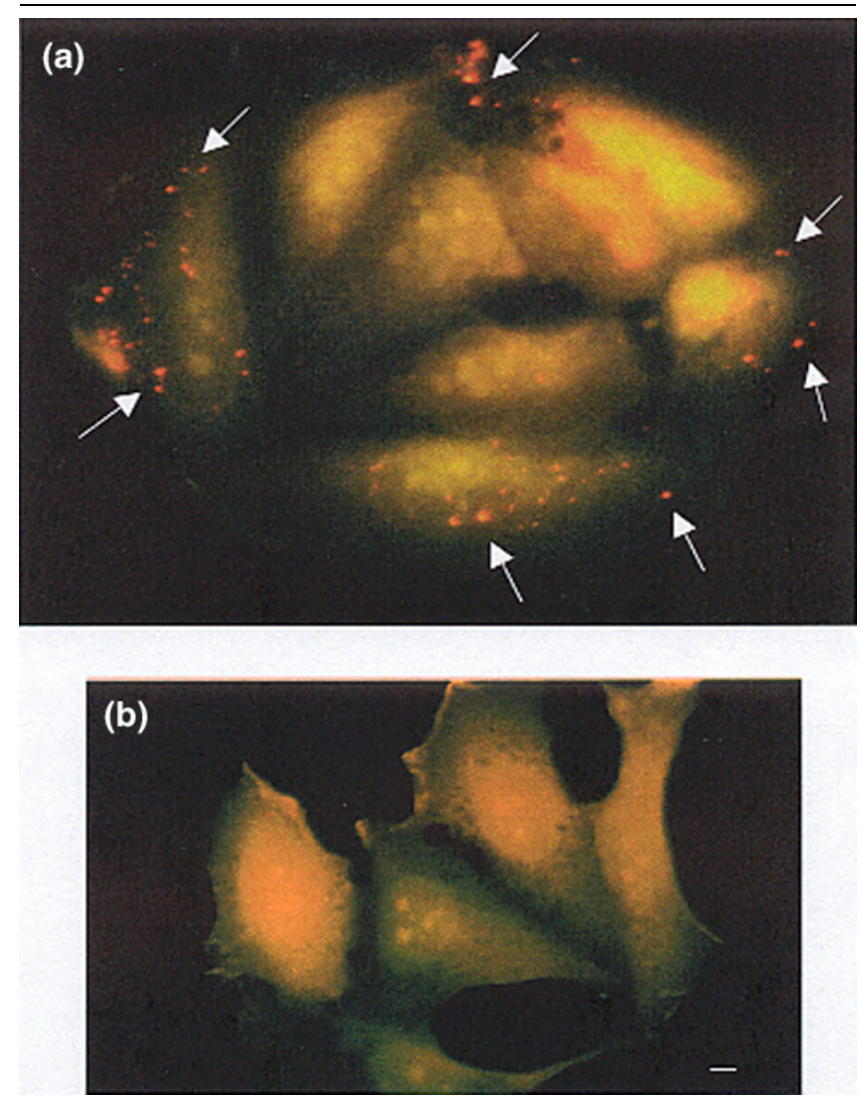

Fluorescence immunocytochemical detection of membrane estrogen receptor (mER)- $\alpha$ in nonpermeabilized MCF-7 cells. Cells were fixed with $2 \%$ pararaformaldehyde $/ 0.1 \%$ glutaraldehyde, probed with C-542 carboxyl-terminal estrogen receptor- $\alpha$ antibody, and visualized with a biotinylated secondary antibody-avidin conjugated alkaline phosphatase fluorescent Vector red product. Fluorescence images were photographed using the FITC filter and $100 \times$ magnification. (a) mER$\alpha$-enriched (mERhigh) MCF-7 cells; the arrows indicate some of the punctate staining. (b) mER- $\alpha$-depleted (mER low) MCF-7 cells have no staining. The bar in panel $\mathrm{b}$ represents $10 \mu \mathrm{m}$.

signal was specific for C-542 ER- $\alpha$ antibody, we performed an epitope competition (preblocking of antibody with peptide representing the epitope). We identified two ER- $\alpha$ bands competable with peptide: the $67 \mathrm{kDa}$ (the size of classical ER- $\alpha$ ) and a prominent lower band at $52 \mathrm{kDa}$ (Fig. $3 \mathrm{~b}$, compare panels 1 and 2).

To quantify mER- $\alpha$ with our plate assay, we first determined the lowest optimal C-542 antibody concentration that would saturate binding to the membrane form of the receptor, and then optimized assay conditions to give a reliably detectable signal in the linear range of the fluorescent product assay. All three signal generation incubation times (5, 15 and $30 \mathrm{~min}$ ) gave acceptable data, but 15 min assays allowed clear delineation of antigen-saturating concentrations of C-542 antibody utilizing lower antibody concentrations $(8 \mu \mathrm{g} / \mathrm{ml}$; Fig. $4 \mathrm{a})$. Those conditions were used for
Figure 2

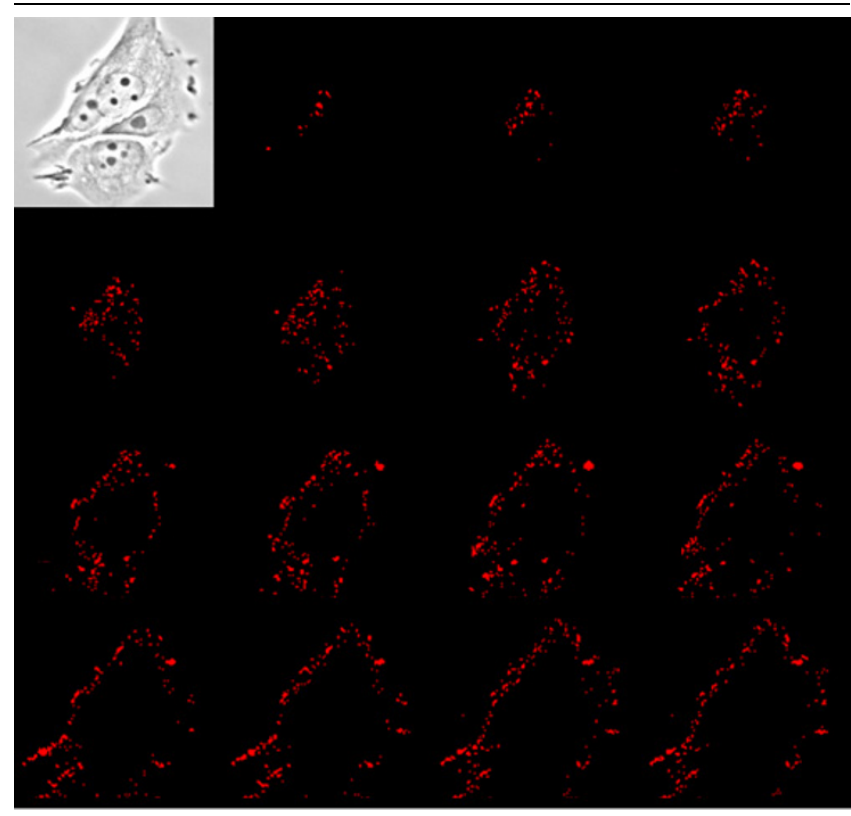

Digital deconvolution of membrane estrogen receptor (mER)- $\alpha$ fluorescent image in mER- $\alpha$-enriched (mERhigh) MCF-7 cells. Fifteen different focal planes starting from the top of the cells and moving toward the bottom are displayed. The sequential slices are from left to right in each row of images. These cells are nonpermeabilized and treated as described in the previous figure legend. The corresponding transmitted light image is displayed in the upper left-hand corner. FITC filter images were captured, pseudo-colored, and processed by digital deconvolution.

subsequent assays. The same level of mER- $\alpha$ could be detected in cells kept for 3 days in a completely defined medium lacking serum or in the same medium supplemented with 10\% DCSS (Fig. 4a, open circles and closed circles, respectively). The background values (obtained in the absence of primary and secondary antibody, or with no primary antibody) were very low (Fig. 4b). At $8 \mu \mathrm{g} / \mathrm{ml}$ the isotype control $\mathrm{mlgG}_{1 \mathrm{k}}$ yielded a value only $10 \%$ of that for C-542 antibody; peptide competition resulted in an approximate $50 \%$ decrease in C-542 antibody binding, again verifying the specificity of the antibody for this epitope. This verified that the assay was specific, and not subject to interference by endogenous alkaline phosphatases in the presence of levamasole. The fixation conditions that we used preserved the integrity of the cell membrane, as demonstrated by the negligible anti-clathrin antibody binding in nonpermeabilized versus the very high binding in permeabilized cells. Therefore, equivalent protocols differing only in the inclusion of a permeabilization agent during fixation can be used to quantify the total ER (tER) versus the mER.

Because we had previously observed an effect of cell density on the level of ER expression in $\mathrm{GH}_{3} / \mathrm{B} 6 / \mathrm{F} 10$ cells, which occurred at a density when cells had just begun to make contact by cell processes [24], we wondered 
Figure 3

(a)

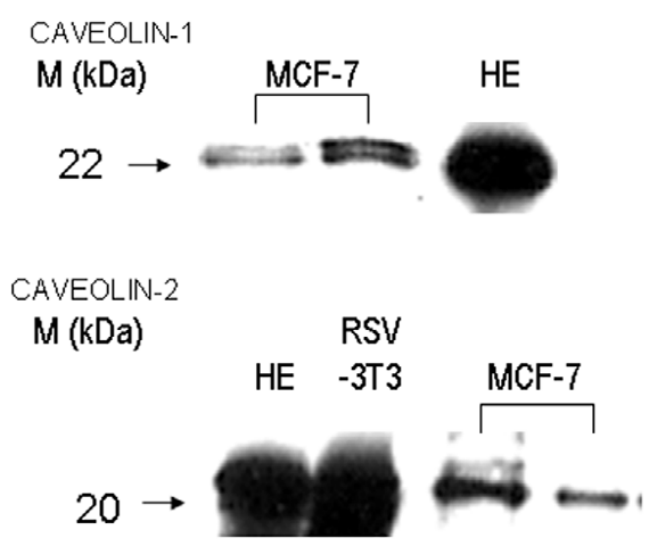

(b)

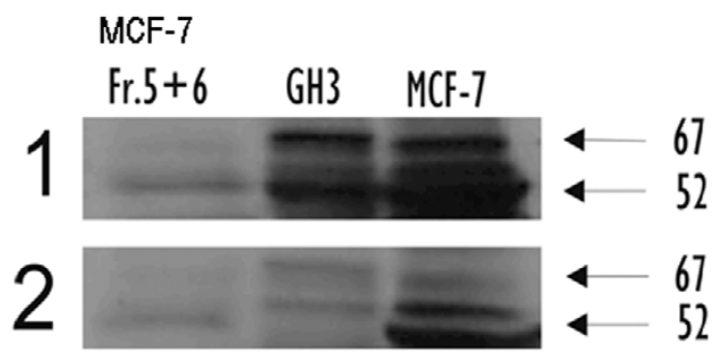

Identification of membrane estrogen receptor (mER) in caveolae by Western blot analysis. (a) Caveolin-1 (upper panel) and caveolin-2 (lower panel) in MCF-7 cell membranes. Membrane fractions containing caveolae were separated on discontinuous sucrose gradients. Fractions 5 and 6 were combined and 20 and $40 \mu \mathrm{g} / \mathrm{ml}$ protein (shown by adjacent lanes with connecting bar) were resolved on a 4-20\% SDSpolyacrylamide gel, transferred to a nitrocellulose membrane, and probed with specific antibodies. Fractions from human endothelial (HE) and mouse fibroblast (RSV-3T3) cells were used as positive controls ( $50 \mu \mathrm{g} / \mathrm{ml}$ protein). (b) Whole cell lysates $\left(\mathrm{GH}_{3}, \mathrm{MCF}-7\right)$ and pooled membrane fractions 5 and 6 (Fr.5+6) from sucrose gradients for MCF7 cells were probed with estrogen receptor- $\alpha$-specific antibody C-542 (panel 1) or the same antibody blocked with the epitope peptide (panel 2). The arrows show the positions of major bands that were identified as receptor by epitope competition (at 67 and $52 \mathrm{kDa}$ ).

whether the same regulation was applicable to breast cancer cells. Considering this effect, plating a single density may not demonstrate the ability of cells to express $m E R-\alpha$. Therefore, we performed a cell density study for $m E R^{\text {high }}$ versus $m E R^{\text {low }}$ breast cancer cell types (Fig. 5). The mER- $\alpha$ signal decreased exponentially with increasing cell number (Fig. 5a). At low plating densities, mER high cells clearly showed much higher levels of $m E R$ than did $m E R^{\text {low }}$ cells (Fig. 5, closed circles and open circles, respectively). The two curves approximating the level of $m E R$ were significantly different $(P=0.0003)$. The ER- $\alpha$-negative cell line MDA-MB-231 did not have mER- $\alpha$ (Fig. 5 , diamond), even at relatively low cell density, because their value was at the level of $\mathrm{mlgG}_{1 \mathrm{k}}$ isotype control antibody levels (horizontal
Figure 4

(a)

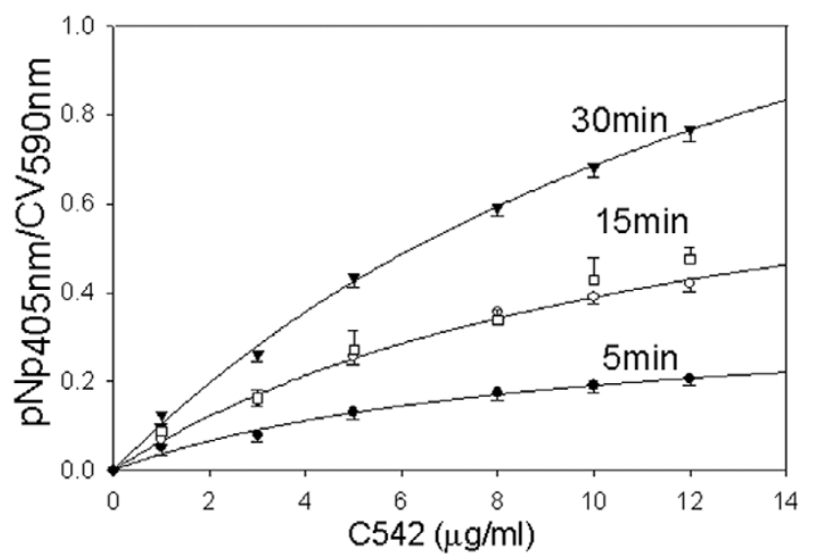

(b)

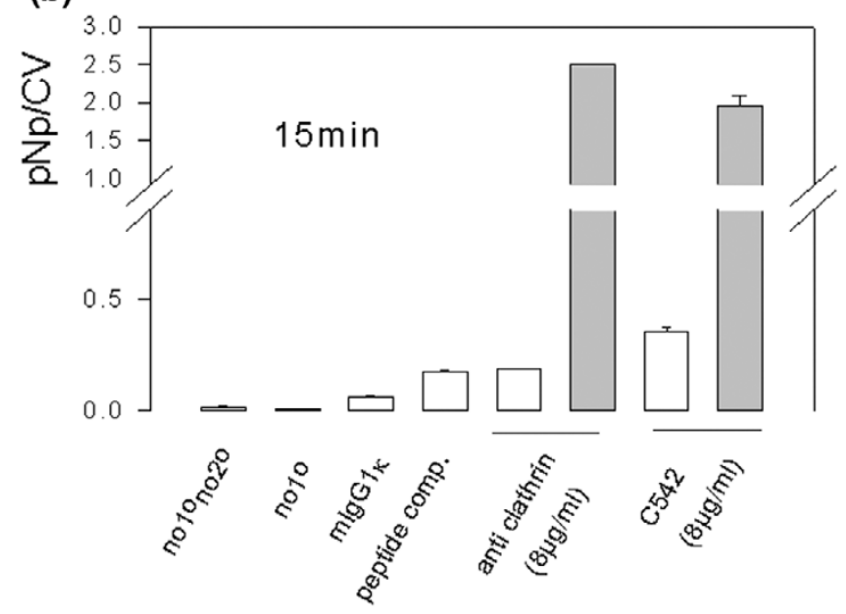

Optimization of 96-well plate immunoassay for membrane estrogen receptor (mER) quantification in MCF-7 cells. (a) Different concentrations of estrogen receptor- $\alpha$-specific $C-542$ antibody $(1-12 \mu \mathrm{g} / \mathrm{ml})$ were tested. Enzymatic paranitrophenol phosphate (pNpp) hydrolysis yielding the paranitrophenol ( $\mathrm{pNp}$ ) product was monitored at $37^{\circ} \mathrm{C}$ for 5,15 and $30 \mathrm{~min}$, as shown. Cells pretreated for 72 hours with medium containing dextran-coated charcoal-stripped serum (DCSS) versus defined medium (DM) are represented with closed and open circles, respectively. (b) Antibody binding compared in nonpermeabilized (open bars) and permeabilized (shaded bars) conditions. no $1^{\circ}$ no $2^{\circ}$ represents primary and secondary antibodies omitted; no $1^{\circ}$ represents primary antibody omitted (only secondary antibody applied); mlgG1k represents mouse $\lg _{1 \mathrm{k}}$ isotype control; peptide comp. represents C-542 epitope peptide blocking of the interaction with primary antibody; anticlathrin represents our test for cell membrane integrity. Values are expressed as means \pm standard error. $\mathrm{CV}$, crystal violet.

hatched line). Increased cell density also decreased tER (Fig. 5b); however, mER high and mER ${ }^{\text {low }}$ MCF-7 cells exhibited the same level of $t E R$, because all of these data could be approximated with the same curve. Because $m E R$ high cells had higher mER- $\alpha$ levels but the same tER- $\alpha$ levels as mERlow cells, then, by subtraction, mER ${ }^{\text {high }}$ cells have lower intracellular ER- $\alpha$ levels than do mER low cells. 
Figure 5

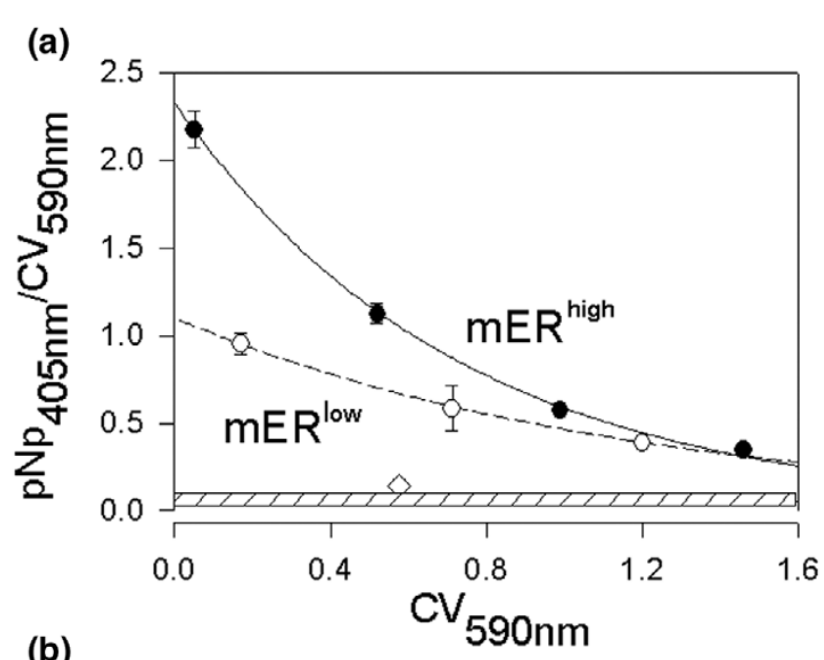

(b)

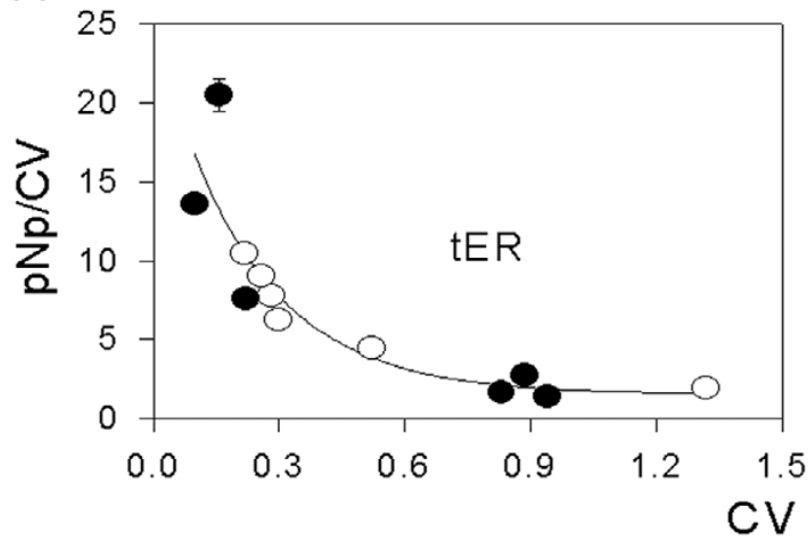

Quantification of membrane estrogen receptor ( $\mathrm{mER}$ ) and total estrogen receptor (tER) in mER- $\alpha$-enriched (mER high) and mER- $\alpha$-depleted (mER low) MCF-7 cells. (a) Different numbers of cells were fixed in the same manner as described in Fig. 1 and the level of mER was assessed with $8 \mu \mathrm{g} / \mathrm{ml} \mathrm{C}-542$ antibody. Closed and open circles represent mERhigh and $m E R^{\text {low }}$ cells, respectively. The data were approximated with an exponential decay curve and compared by evaluating the difference between the sums of squares of the residuals from each curve with the sum of squares of the residuals for the combined curve using the F-test. The curves are significantly different $(P=0.0003)$. The diamond represents MDA-MB-231 cells and the cross-hatched horizontal bar the leve of binding of a mouse $\lg G_{1 k}$ isotype control antibody. (b) Level of total $E R$ (intracellular estrogen receptor [iER] plus $\mathrm{mER}$ ) for $\mathrm{mER}$ high (closed circles) and mERlow (open circles) under the same binding conditions except for permeabilization of the cells. Where error bars for standard error are not visible, they are smaller than the size of the symbols. CV, crystal violet; $\mathrm{pNp}$, paranitrophenol.

\section{Kinetics of ERK1/2 activation by $17 \beta$-estradiol in MCF-7 cells enriched and MCF-7 cells depleted for membrane ER- $\alpha$}

During the optimization of the fixed cell-based enzymelinked immunosorbent assay for ERK activation, we established the optimal cell density for a 10 min EGF treatment, which is known to result in substantial phosphorylation of ERK1/2. Both the controls and EGF-treated cells exhibited increased pERK1/2 with increased cell number (Fig. 6a, main graph). As we expected, normalizing pERK1/2 values to the number of cells (CV absorbance at $590 \mathrm{~nm}$ ) did not significantly change the ratio values except in the case of the highest number of cells plated, verifying that cells plated in the density range of $\mathrm{CV}$ values $0.2-0.6$ could be used. Partly because others have shown that ERKs can be activated by mechanical stimulus in MCF-7 cells [29], we tested ethanol-treated controls over the same time course (3-60 min). A pronounced decrease in ERK1/2 phosphorylation was seen with time (Fig. 6b), and so appropriate controls were performed for each time point in all subsequent experiments.

In mERhigh MCF-7 cells, ERK $1 / 2$ activation with 1 pmol/l $\mathrm{E}_{2}$ was fast and transient (Fig. 7a). The maximal activation was achieved after $10 \mathrm{~min}$, followed by a rapid decline in phosphorylated ERK1/2. However, continued incubation with $\mathrm{E}_{2}$ (1 hour) resulted in the reactivation of ERK1/2. To test whether this signal was initiated at the membrane, the impeded ligand $E_{2}$-peroxidase was applied to the cells at steroid concentrations that approximated the levels applied as free steroid in the previous experiments (Fig. 7b). To eliminate any free steroid present, just before use we pretreated the $\mathrm{E}_{2}$-peroxidase with dextran-coated charcoal under conditions that remove more than $99 \%$ of free hormone [9]. The resulting maximal level of ERK1/2 activation was slightly higher than for treatment with the free ligand, but the peak time of activation was the same. Again, a recurrent later ERK activation was observed.

Cells with lower levels of mER- $\alpha$ (Fig. 7c) also had the capacity for fast and transient activation of ERK1/2, but this smaller activation peak appeared at $6 \mathrm{~min}$ after $1 \mathrm{pmol} / \mathrm{l} \mathrm{E}_{2}$ treatment. The levels of phosphorylated ERK declined between 10 and 30 min of $E_{2}$ treatment as they had with mERhigh cells; however, at longer incubations ( 1 hour) no reactivation was seen but rather a further ERK1/2 apparent dephosphorylation was observed. This implies that higher levels of mER- $\alpha$ associated with more robust early ERK activation are also responsible for the sustained ERK reactivation at the later stage.

The inhibitor of the upstream MEK1/2, namely U0126, was effective in inhibiting ERK1/2 activation in both types of MCF-7 cells (Fig. 6a and 6c, insets), verifying that the values we measured in our plate assay were from MEK-phosphorylated ERK. In the MDA-MB-231 ER- $\alpha$-negative cell line (Fig. 7d), $E_{2}$ could not significantly activate ERK1/2, confirming that ER- $\alpha$ is necessary for ERK activation during this 60 min time period. 
Figure 6
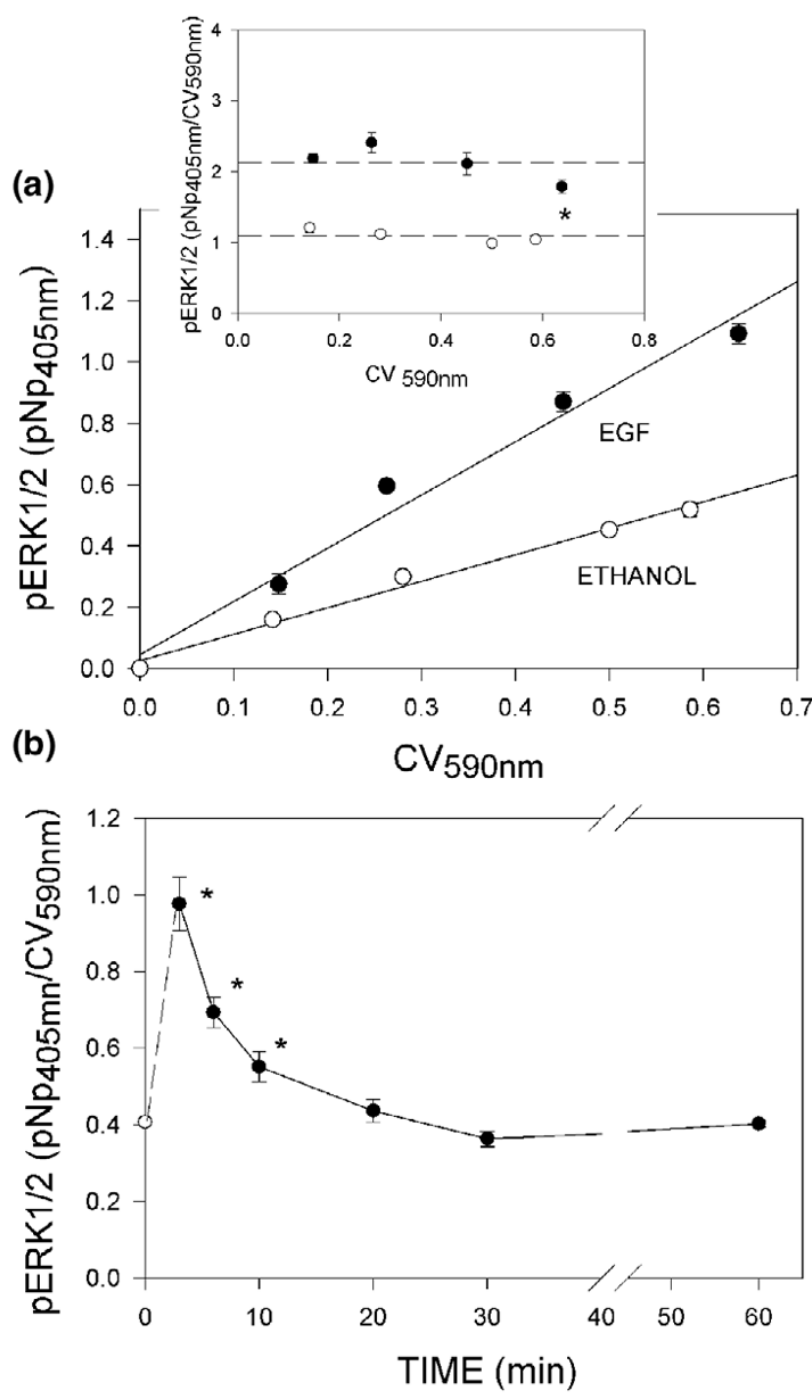

Optimization of fixed cell-based enzyme-linked immunosorbent assay for mitogen-activated protein kinase using epidermal growth factor (EGF) stimulation. (a) Different numbers of cells were treated for 10 min with $50 \mathrm{ng} / \mathrm{ml} E G F$, fixed, and the level of extracellular signal-regulated kinase (ERK) 1/2 phosphorylation determined using a phosphospecific antibody and the Vectastain $A B C$ alkaline phosphatase kit with paranitrophenol phosphate (pNpp) substrate. Inset: values for paranitrophenol $(\mathrm{pNp})$ normalized against the number of cells determined by the crystal violet $(\mathrm{CV})$ assay. Closed and open circles represent EGF and vehicle treatment, respectively. (b) Time course of ERK stimulation by vehicle. Open circle: zero time point estimated by averaging 20, 30 and $60 \mathrm{~min}$ values of vehicle treatment. Asterisks indicate significant differences $(P<0.05)$ compared with all other values. Values are expressed as means \pm standard error.

Dose-dependent activation of ERK1/2 by $17 \beta$-estradiol is influenced by the level of membrane ER- $\alpha$ expression In mERhigh cells, the ability of $E_{2}$ to induce ERK activation was biphasic with respect to dose at the $10 \mathrm{~min}$ time point (early response peak). ERK phosphorylation was stimu- lated at a wide range of concentrations from $0.1 \mathrm{pmol} / \mathrm{l}$ to $100 \mathrm{nmol} / / \mathrm{E}_{2}$, although the highest $\mathrm{E}_{2}$ concentrations resulted in less phosphorylation (Fig. 8a). In mER low cells a biphasic response was also seen, but the only effective concentrations were 0.1 and $1 \mathrm{pmol} / \mathrm{l}$ for the $6 \mathrm{~min}$ (early and only) response peak (Fig. 8b).

\section{Physiologic significance of early ERK1/2 activation}

Long-term treatment of mERhigh MCF-7 cells with 1 pmol/l $E_{2}$ resulted in substantial stimulation of proliferation (Fig. 9). A 10 min short pulse treatment also resulted in significant although lower stimulation of proliferation. The same level of stimulation was achieved with both $\mathrm{E}_{2}$ and $\mathrm{E}_{2}$-peroxidase presented for a short pulse. $E_{2}$-induced proliferation was prevented with MEK inhibitor (U0126) as well as with a specific ER- $\alpha$ antibody recognizing the ligand binding domain. These results are consistent with the participation of mER- $\alpha$ and ERK1/2 in the cell proliferation response.

\section{Phosphatase inhibitors differentially affect ERK activation in MCF-7 cells enriched and depleted for membrane ER- $\alpha$}

We next asked whether the observed decrease in phosphorylated ERK1/2 after 20 min in both subpopulations of cells, and the continued low phosphorylation levels after 60 min in mER low cells, could successfully be abrogated with specific phosphatase inhibitors (Fig. 10). We tested inhibitors of protein phosphatase (PP) 1, PP1A, and PP2B. These phosphatases can be considered principal enzymes of this class, based on their general abundance and broad specificity [30]. Okadaic acid (OA), an inhibitor of PP1 and PP1A, and cyclosporin A, an inhibitor of PP2B, were both able to reverse the ERK inactivation in $m E R$ high cells (Fig. 10a). In mERlow cells, both the 20 min and continued 60 min dephosphorylation were abrogated only with the PP2B inhibitor (Fig. 10b and 10c). Because of the known apoptotic effect of OA at some concentrations [31], it is important to stress that we applied it at a low concentration (50 $\mathrm{nmol} / \mathrm{I})$. In addition, OA does not have toxic effects in shortterm incubations [32]. These results suggest that dephosphorylation of ERKs is an important component of their process of action and that coordinated phosphorylation/ dephosphorylation is required for strong signaling through this pathway.

\section{Rapid effects of ICl182,780 and $17 \alpha$-estradiol on ERK1/2 activation}

To characterize the pharmacologic properties of ERK activation, we used $m E R^{\text {high }}$ cells to study the effectiveness of the potent antiestrogen $\mathrm{ICl} 182,780(1 \mu \mathrm{mol} / \mathrm{l})$ and the inactive $E_{2}$ stereoisomer $17 \alpha$-estradiol (10 nmol/l). We used concentrations of these compounds shown by others to be effective in inhibiting the transcriptional activity of $E_{2}$. We had also previously shown that a $10 \mathrm{nmol} / / 17 \alpha$-estradiol concentration could elicit another type of nongenomic 

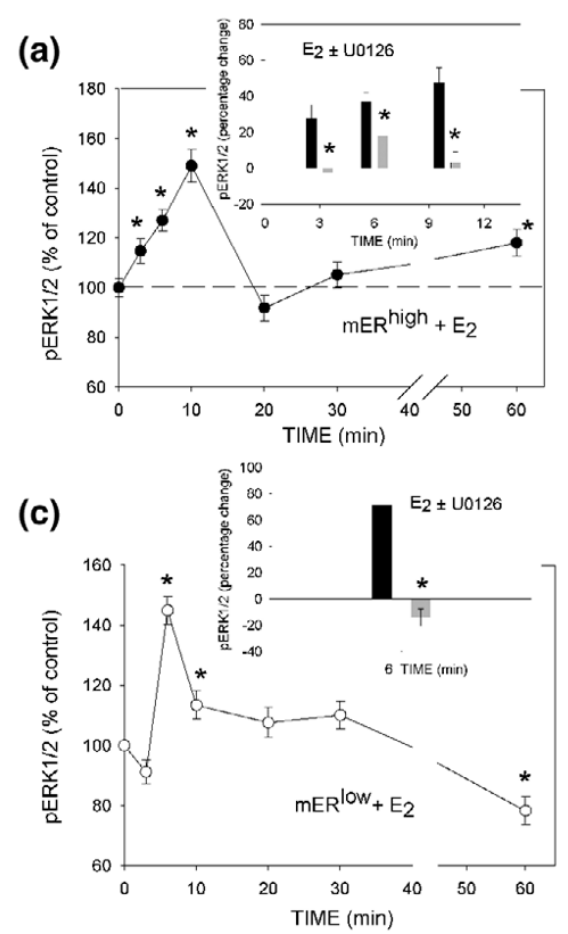

(b)

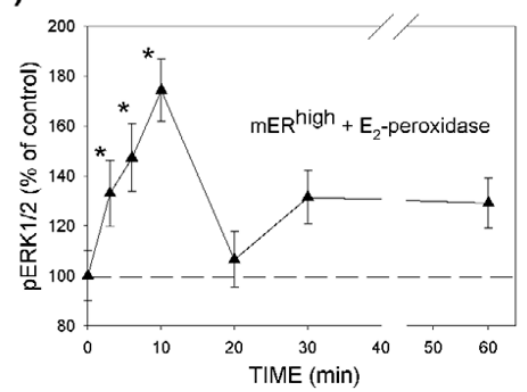

(d)

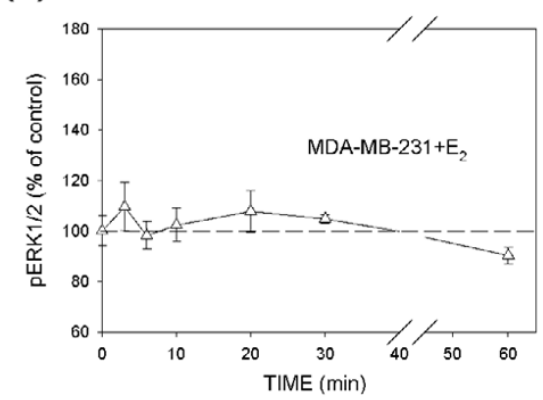

Time course of extracellular signal-regulated kinase (ERK)1/2 activation with $17 \beta$-estradiol $\left(E_{2}\right)$ and impeded ligand in membrane estrogen receptor (mER)- $\alpha$-enriched (mERhigh) and mER- $\alpha$-depleted (mERlow) MCF- 7 cells, and receptor-less cells. After 72 hours in medium with dextran-coated charcoal-stripped serum (DCSS), cells were treated with $1 \mathrm{pmol} / \mathrm{I} \mathrm{E}_{2}$, or an equivalent concentration of hormone contained in an $\mathrm{E}_{2}$-peroxidase conjugate, for different time intervals. (a, b) mERhigh MCF-7 cells treated with $E_{2}$ and $E_{2}$-peroxidase, respectively. (c) mERlow MCF-7 cells treated with $E_{2}$. (d) Estrogen receptor- $\alpha$-negative MDA-MB-231 cells treated with $E_{2}$. Each experiment was repeated at least three times, each time point represents 16 replicate wells, and the values are expressed as mean \pm standard error. Insets: inhibition of ERK1/2 activation with U0126 upstream mitogenactivated protein kinase kinase (MEK) $1 / 2$ inhibitor. The cells were pretreated for $15 \mathrm{~min}$ with $40 \mu \mathrm{mol} / \mathrm{l}$ inhibitor (gray bars) and $\mathrm{E}_{2}$-induced activation of ERK $1 / 2$ was tested at activation times appropriate for each cell type (after 3,6 and $10 \mathrm{~min}$ in the case of mERhigh or 6 min in the case of $\mathrm{mER}$ low cells). The asterisks indicate the significant reduction in ERK1/2 activation compared with cells treated only with $\mathrm{E}_{2}$ (black bars).

estrogenic effect in our $\mathrm{GH}_{3} / \mathrm{B} 6 / \mathrm{F} 10$ pituitary tumor cell model - rapid prolactin release [15]. ICl182,780 alone induced an activation pattern very similar to that seen with $E_{2}$ but with an earlier first peak (Fig. 11a). A $30 \mathrm{~min}$ ICl182,780 preincubation before a subsequent 1 pmol/I $E_{2}$ challenge did not significantly change the $E_{2}$ activation pattern, although the first peak again appeared at $6 \mathrm{~min}$ (the ICl182,780 pattern) and there was a much more pronounced inactivation at 10 and 20 min (compare Fig. 11b with Figs $7 \mathrm{a}$ and 11a). However, simultaneous application of $\mathrm{ICl} 182,780(1 \mu \mathrm{mol} / \mathrm{l})$ and $E_{2}(1 \mathrm{pmol} / \mathrm{l})$ blunted the response and altered the kinetics of ERK phosphorylation, shifting the now single weak activation to later times (2060 min; Fig. 11c). The $\mathrm{E}_{2}$ stereoisomer (17 $\alpha$-estradiol) provoked a slightly delayed and blunted response also, but with some other interesting features (Fig. 11d). A significant dephosphorylation occurred before the major activation peak, a return to baseline phosphorylation levels followed the $20 \mathrm{~min}$ activation peak, and no second activation peak occurred at $60 \mathrm{~min}$.

\section{Discussion}

In the late 1970s, Pietras and Szego [33] reported the presence of high-affinity binding sites for $E_{2}$ associated with the plasma membranes of the MCF-7 human breast cancer cell line. Since that time few laboratories have followed up on this finding [34,35] until very recently, when more detailed studies started to emerge. However, none of these studies established a correlation between the level of identified $m E R-\alpha$ expression and its functions.

To address this issue we used immunopanning followed by FACS to separate MCF-7 cells into two subpopulations that were enriched and depleted for mER- $\alpha$ expression. We then used several approaches to assess the appearance and levels of $m E R-\alpha$ in these two subpopulations. These studies demonstrated that MCF-7 cells are heterogeneous with respect to mER- $\alpha$ expression, and that difficulties in reproducibly demonstrating nongenomic estrogenic effects in these cells could in part be due to the dilution of responding cells in the largely nonresponsive total cell population. We were able to obtain two distinct cell subpopulations without applying plasmid-based trans- 
Figure 8

(a)

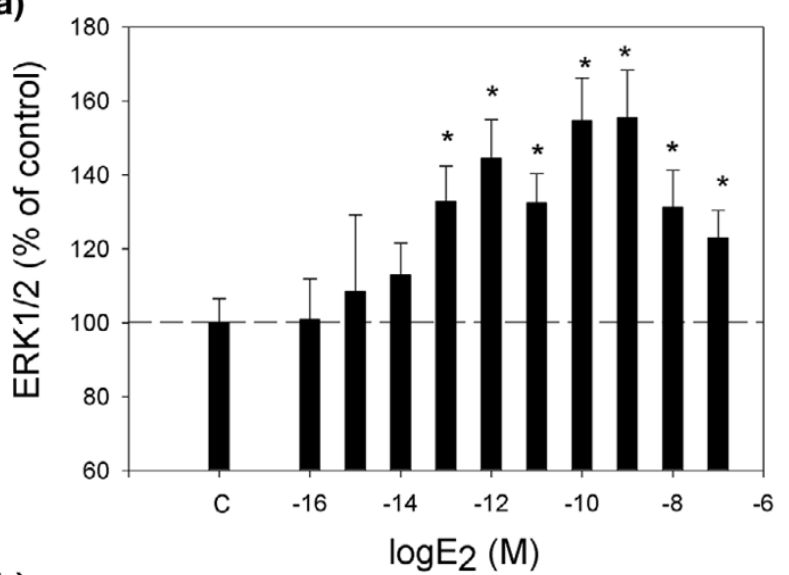

(b)

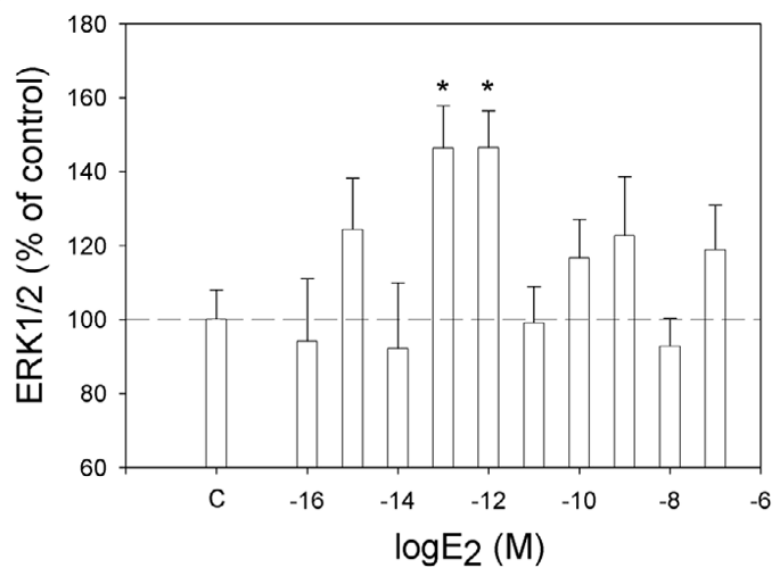

Dose-dependent $17 \beta$-estradiol $\left(E_{2}\right)$ activation of extracellular signalregulated kinase (ERK) $1 / 2$ in membrane estrogen receptor (mER)- $\alpha$ enriched ( $m E R^{\text {high}}$ ) versus $m E R-\alpha$-depleted (mERlow) MCF-7 cells. Cells were incubated with different $E_{2}$ concentrations at peak activation times: (a) $10 \mathrm{~min}$ in the case of mERhigh and (b) $6 \mathrm{~min}$ in the case of mER low. The experiments were repeated three times, each with 16 replicates; values are expressed as mean \pm standard error. The asterisks indicate significant differences from the vehicle controls (C).

fection manipulations to over-express receptor (with probable accompanying altered regulatory parameters). Our experimental model avoids changes in stoichiometry of the multiple interacting proteins that are involved in steroid actions. Because our mERhigh and $\mathrm{mER} \mathrm{R}^{\text {low }}$ cells were not clonally derived (from a single cell), the observed differences between these subpopulations cannot be attributed to clonal variations.

A characteristic punctate staining for $\mathrm{mER}$ (earlier reported for $\mathrm{GH}_{3} / \mathrm{B} 6 / \mathrm{F} 10$ cells [22]) was also detected on the surface of most of our mERhigh MCF-7 cells. MCF-7 mERlow cells also had occasional punctuate staining, but at a much lower level. Because it is difficult and time-consuming to quantify this staining via immunocytochemistry, we modi-
Figure 9

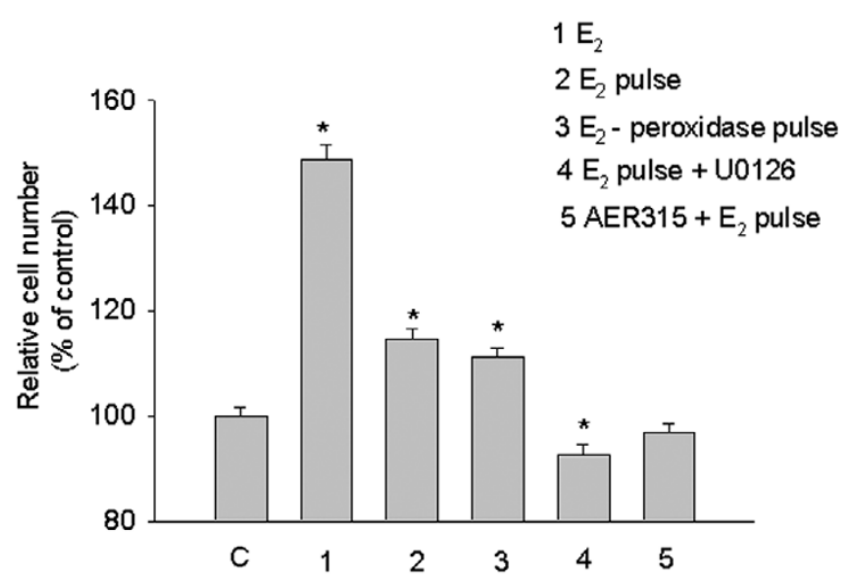

Pulsed effect of $17 \beta$-estradiol $\left(E_{2}\right)$ and conjugated $E_{2}$ on cell proliferation. MCF-7 membrane estrogen receptor (mER)- $\alpha$-enriched (mERhigh) MCF- 7 cells were treated for 5 days (bar 1 ) or 10 min with $1 \mathrm{pmol} / / \mathrm{E}_{2}$ (bar 2) or $\mathrm{E}_{2}$-peroxidase containing the equivalent of $1 \mathrm{pmol} / / \mathrm{E}_{2}(\mathrm{bar} 3)$. In bar 4, pretreatment with U0126 (40 $\mu \mathrm{mol} / \mathrm{l})$ for $15 \mathrm{~min}$ was followed by 10 min treatment with $E_{2}$. Bar 5 shows blockage of mER- $\alpha$ by incubating the cells for 1 hour at room temperature with $1 \mu \mathrm{g} / \mathrm{ml}$ of a ligand binding domain-specific antibody and the subsequent effect of $10 \mathrm{~min}$ incubation with $E_{2}$. These experiments were repeated three times, each with 40 well replicates; values are expressed as mean \pm standard error. The asterisks indicate significant differences from the controls $(C-$ ethanol vehicle, inhibitor, or antibody treatment alone).

fied our previously developed 96-well plate immunoassay [23] to measure both membrane and intracellular receptors in breast cancer cells, and to quantitate the relative amounts in these two receptor subpopulations. This assay must be tailored to specific cell types to ensure preservation of the membranes (which have quite different compositions in different cell types) and to optimize for different antibody labeling systems. Although $m E R-\alpha$ levels differed between the two cell types named for these differences (high versus low), we discovered that the two subpopulations had the same quantity of total receptor (measured in permeabilized cells). This finding is consistent with intracellular and membrane fractions of ER- $\alpha$ being from the same ER pool, but with a different balance of subcellular distribution.

There is disagreement in the literature on the expression of caveolin-1 and - 2 in MCF- 7 cells. To test whether mER is localized in caveolar membranes, we had first to resolve this uncertainty. Some have reported that in MCF-7 cells caveolin-1 is downregulated and only caveolin-2 is expressed $[36,37]$. Others reported that caveolin-1 could be upregulated and downregulated in MCF-7 cells in concert with the cells' ability to develop drug resistance [38]. Some studies used transient transfection to re-express the missing caveolin-1 and test for its function in signaling $[7,39]$. Apparently, there are several different subpopulations of MCF-7 cells growing in different laboratories 
Figure 10

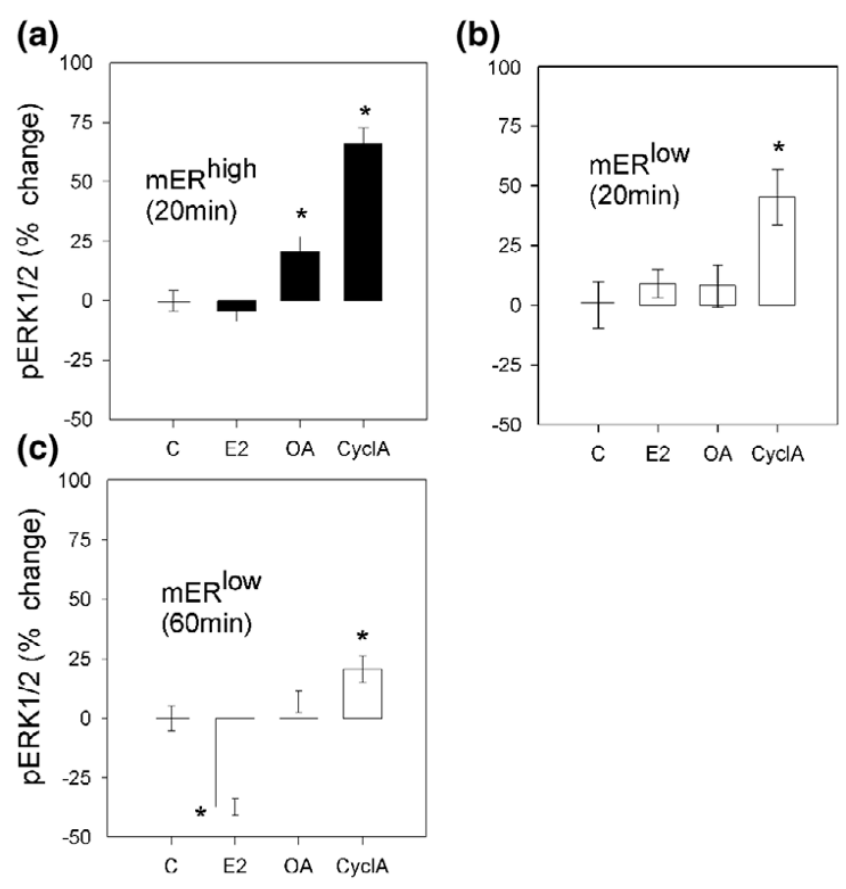

Effects of phosphatase inhibitors on extracellular signal-regulated kinase (ERK) $1 / 2$ dephosphorylation. Cells were pretreated for 1 hour with different phosphatase inhibitors: $50 \mathrm{nmol} / \mathrm{l}$ okadaic acid (OA) or 3 $\mu \mathrm{mol} / \mathrm{l}$ cyclosporin A (CyclA). Then, ERK1/2 phosphorylation was determined after $1 \mathrm{pmol} / \mathrm{l} \mathrm{E}_{2}$ stimulation for (a,b) $20 \mathrm{~min}$ or (c) $60 \mathrm{~min}$. Black bars are membrane estrogen receptor (mER)- $\alpha$-enriched (mERhigh) MCF-7 cells; open bars are mER- $\alpha$-depleted (mERlow) MCF-7 cells. The data are averages of two or three experiments, each with 24 replicates; values are expressed as mean \pm standard error. The asterisks indicate significant differences from the vehicle control-treated samples with corresponding inhibitor included.

$[40,41]$. Our MCF-7 cells expressed both caveolin-1 and 2 , and ER- $\alpha$ was associated with the same gradient fractions in which most of the caveolin proteins were detected. A $67 \mathrm{kDa}$ ER and a variant of lower molecular weight (52 $\mathrm{kDa}$ ) were detected in both the cell lysate and the caveolar membrane gradient fractions. Until recently the lower molecular weight ER variants were thought to be proteolytic fragments, but evidence that some of those molecules are truncated products of the full-length ER- $\alpha$ was recently presented. It is well documented that in MCF- 7 breast cancer cells ER- $\alpha$ mRNA can undergo alternative splicing, generating transcripts with single, double, or multiple exon deletions [42], and that a $52 \mathrm{kDa}$ protein is translated from the predominant splice variant mRNA that is missing exon 7 [43]. Others have identified a $46 \mathrm{kDa}$ variant in human endothelial cells [44] and in MCF-7 cells $[45,46]$. Some evidence suggests that the $46 \mathrm{kDa}$ receptor is the major functional membrane form of ER [44]; however, the precise functions of the truncated ER- $\alpha$ s are still under investigation.
The traditional detection and quantitation of phosphorylated MAPKs via Western blot analysis is laborious and somewhat arbitrary in the designation of appropriate densitometric backgrounds for comparison, especially in situations where the significant activation response is not large. We developed an enzyme-linked immunosorbent assay to deal with these experimental problems using fixed cells [47], which allowed convenient testing of large numbers of different conditions. Ours is the first report that different levels of $\mathrm{mER}$ in MCF-7 cells influence the different temporal and dose-dependent estrogen-induced phosphorylations of ERKs. The subpopulation of cells with high mER levels exhibited early and more robust activation, peaking at $10 \mathrm{~min}$ with a reactivation at $60 \mathrm{~min}$, whereas the subpopulation of cells with low mER levels were only capable of weakly activating ERKs at one early time point $(6 \mathrm{~min})$. Furthermore, in the ER- $\alpha$-negative cell line MDA-MB-231, $E_{2}$ could not activate these kinases. The physiologic significance of early ERK1/2 activation was confirmed by showing that short pulse $E_{2}$ treatment also stimulated cell proliferation. We and others [46] have confirmed that mER$\alpha$ in breast cancer cells is responsible for this effect by showing that $\mathrm{E}_{2}$-peroxidase can stimulate proliferation and that this effect can be abolished by prior blocking of ER- $\alpha$ with ligand-binding domain-specific antibody.

The inability to activate ERKs with $E_{2}$ in an ER- $\alpha$-negative cell line, and the ability to do so in MCF-7 ER- $\alpha$-positive cells, was assigned by others to the orphan G-protein-coupled receptor GPR30 [48]. However, recent studies with antisense GPR30 knockdowns revealed that $E_{2}$-stimulated MCF-7 cells proliferate as well as cells with normal levels of GPR30 [49,50]. ERK activation associated with the ability of these cells to respond to estrogens by proliferating thus does not appear to be a function of GPR30 levels.

Different levels of $m E R$ also determined the $E_{2}$ dosedependent phosphorylation of ERKs. Cells with low levels of $\mathrm{mER}$ responded to a limited range of concentrations (1013 to $\left.10^{-12} \mathrm{~mol} / \mathrm{l}\right)$. However, $\mathrm{mER}$ high cells responded to a much wider range of $E_{2}$ concentrations $\left(10^{-13}\right.$ to $\left.10^{-7} \mathrm{~mol} / \mathrm{l}\right)$ with a declining (but still significant) ERK activation at 10$100 \mathrm{nmol} / \mathrm{l} \mathrm{E}_{2}$. This finding corresponds to our observation that $10 \mathrm{nmol} / \mathrm{l}$ and higher $\mathrm{E}_{2}$ decreases cell proliferation in mERhigh MCF- 7 cells, and is consistent with the idea that $E_{2}$ induces CAMP-activated protein kinase $A$ inhibition of MAPK pathways at these higher concentrations (see accompanying paper [28]). Activation of ERKs has been linked to the proliferative cellular response [51]. Our accompanying report [28] addresses other rapid estrogenelicited signaling responses that, in concert with ERK activation, can affect and perhaps balance cell proliferation responses. 
(a)

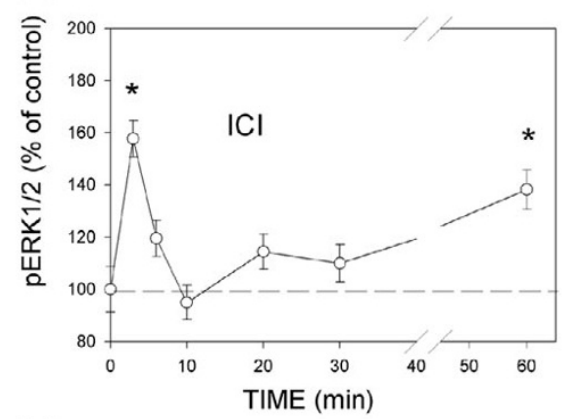

(c)

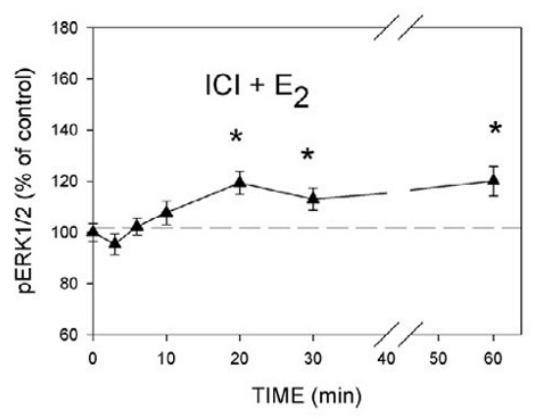

(b)

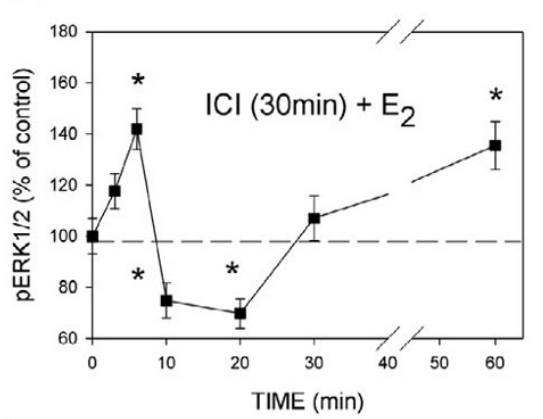

(d)

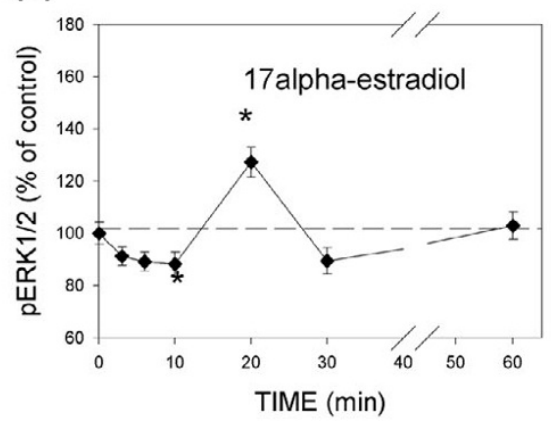

Effects of $\mathrm{ICl} 182,780(\mathrm{ICl}), \mathrm{ICl}+17 \beta$-estradiol $\left(\mathrm{E}_{2}\right)$, and $17 \alpha$-estradiol on extracellular signal-regulated kinase (ERK) $1 / 2$ activation in membrane estrogen receptor- $\alpha$-enriched (mERhigh) MCF-7 cells. (a) Time course of ERK1/2 activation by $1 \mu \mathrm{mol} / \mathrm{I} \mathrm{ICl}$. (b) Pretreatment with ICl $(1 \mu \mathrm{mol} / \mathrm{I})$ for $30 \mathrm{~min}$ followed by $1 \mathrm{pmol} / / \mathrm{E}_{2}$ stimulation in the continued presence of $\mathrm{ICl}$. (c) $\mathrm{ICl}(1 \mu \mathrm{mol} / \mathrm{I})$ and $\mathrm{E}_{2}(1 \mathrm{pmol} / \mathrm{l})$ applied simultaneously. (d) Time course of $17 \alpha$-estradiol $(10 \mathrm{nmol} / \mathrm{l})$ activation of ERK1/2. All experiments were repeated at least three times with 24 well replicates/experiment; the averaged values \pm standard error are presented. The asterisks indicate significant differences from vehicle controls.

The classical antiestrogen ICl182,780 has been well defined as an antagonist of the action of estrogen at the transcriptional level. In our studies this compound was also a potent and rapid ERK activator. With different kinetics, the transcriptionally inactive $17 \alpha$-estradiol also activated ERKs. It has been demonstrated that pure antiestrogen-ER complex can bind to estrogen response elements, but that the resultant transcriptional unit is inactive [52]. This binding and inactivation is generally used for pharmacological identification of ER- $\alpha$ participation in gene transcription. However, in a yeast reporter system antiestrogens (ICl182,780 and tamoxifen) induce ER dimerization and transcriptional activity [53]. Thus, although the published data disagree, it remains possible that antiestrogen-ER complexes can exert rapid effects such as induction of ERK phosphorylation and other signaling effects [54,55].

Other differences between findings may stem from effects assessed at different time points [56-58]. The length of time between estrogen or antiestrogen administration and kinase assessment can clearly influence outcomes, as evidenced by our time- and compound sequencing-dependent changes in ERK activation. It is also known that lengthy exposures to $\mathrm{ICl} 182,780$ can dramatically decrease ER- $\alpha$ protein levels $[47,52]$, which could explain the decreased ERK activation observed in some studies. Long-term estrogen-deprived MCF-7 cells express higher levels of ER than do wild-type MCF-7 cells and are hypersensitive to $E_{2}$; ICl182,780 did not alter the pattern of response to $E_{2}$-stimulated growth in these cells $[59,60]$. To reconcile this observation with the expected inhibitory effect of $\mathrm{ICl} 182,780$, the authors suggested that $\mathrm{ICl} 182,780$ blocked only the effect of the residual $E_{2}$ coming from plastic tissue culture flasks, without affecting the added $\mathrm{E}_{2}$. We can speculate that the observed effect of ICl182,780 was genuine and resulted from potentially increased levels of $\mathrm{mER}$ in long-term estrogen deprived MCF-7 cells, because our previous studies suggested that serum deprivation elevates mER- $\alpha$ levels [61]. In other cell types ICl182,780 behaved as a potent agonist of ERK1/2 activation (e.g. in rat cerebellar neurons expressing plasmid-generated ERs [60]), or as a partial ER agonist (in the superficial stroma and glandular epithelium of the sheep uterine endometrium [62]). It is likely that subtle differences in the shape of estrogen- and antiestrogen-liganded ERs, whether nuclear or membrane, present different interaction platforms for a variety of co-modulators, and that each signaling pathway must 
be considered in the context of a particular cell type's repertoire of partnering proteins.

In addition to having positive effects by itself, ICl182,780 was able to alter the $\mathrm{E}_{2}$ response differently, dependent on the timing of its administration. If the cells were pretreated for only 30 min (the time point when ICl182,780 alone did not change basal ERK activation), then the initial $\mathrm{E}_{2}$ activation and the late re-activation at $60 \mathrm{~min}$ were preserved, whereas the after-peak deactivation was enhanced. If ICl182,780 and $E_{2}$ were added simultaneously, then the activation was delayed to $20 \mathrm{~min}$, but weakly persisted up to 1 hour. Similar observations that ICl182,780 can change the time of ERK activation were reported in the case of a human thyroid carcinoma cell line, in which it reduced the $30 \mathrm{~min}$ to 1 hour activation, but enhanced later sustained activation at 6 hours [63]. The same authors showed that, in differentiated thyroid gland carcinoma cells (XTC133), addition of ICl182,780 induces a small decrease in the sustained ERK phosphorylation. Thus, in addition to demonstrating that ICl182,780 is not just an antagonist for this response, these studies and ours may point to cell-specific differences in ERK regulation.

Phosphorylations leading to activation and subsequent inactivation of proteins are important regulatory mechanisms for control of cell growth and differentiation $[64,65]$. Although ERKs are thought to play a key role in cell proliferation, it has been suggested that persistent activation of ERKs might result in cell cycle arrest and differentiation in PC12 cells, or cell growth inhibition and apoptosis in normal rat hepatocytes and several human tumor cell lines [65]. However, a detailed time course and transient ERK activations, interspersed with phosphatase-mediated inactivations, are rarely addressed. We (in the present study) and others [66] showed that the serine/threonine phosphatases PP1 and PP2A participate in the dephosphorylation of ERKs. It is interesting that OA (a PP1 and PP2A inhibitor) was more effective in $\mathrm{mER}$ high cells, whereas cyclosporin A (a PP2B inhibitor) was almost equally efficient in both cell populations. These data suggest that the level of mER- $\alpha$ expression/activation can be associated with activation of different types of ERK-modulating phosphatases. Other phosphatases, such as tyrosine phosphatase and dual specificity phosphatases (which dephosphorylate tyrosine, threonine, and serine residues), have been implicated in ERK dephosphorylation $[67,68]$ and will be the subject of our future studies.

Additional studies of ERK activations, deactivations, and stability will be needed before we can formulate a more global picture of the post-translational modifications that lead to function of this important group of regulators in proliferation and differentiation. However, it is clear that nong- enomic estrogen actions and the membrane receptors through which they act participate in this regulation.

\section{Conclusion}

$\mathrm{E}_{2}$-induced changes in breast cancer cell number [28] can be directly related to ERK $1 / 2$ activation/deactivation patterns and interacting signaling mechanisms. The differential behavior of cell lines expressing different levels of mER- $\alpha$ suggests a role for this receptor in the temporal coordination of phosphorylation/dephosphorylation events affecting the mitogen-activated kinases ERK1 and ERK2.

\section{Competing interests}

The author(s) declare that they have no competing interests.

\section{Acknowledgements}

We thank Dr David Konkel for critically reviewing this paper and Dr Bahiru Gametchu for assistance in the FACS separation of cell subpopulations. This work was supported by grants \# DAMD17-01-1-0418 and \#DAMD17-01-1-0649 from Department of Defense Breast Cancer Research Program.

\section{References}

1. Tsai MJ, O'Malley BW: Molecular mechanisms of action of steroid/thyroid receptor superfamily members. Annu Rev Biochem 1994, 63:451-486.

2. Watson CS, Gametchu B: Proteins of multiple classes participate in nongenomic steroid actions. Exp Biol Med (Maywood) 2003, 228:1272-1281.

3. Watson CS, Gametchu B: Membrane-initiated steroid actions and the proteins that mediate them. Proc Soc Exp Biol Med 1999, 220:9-19.

4. Farach-Carson MC, Davis PJ: Steroid hormone interactions with target cells: cross talk between membrane and nuclear pathways. J Pharmacol Exp Ther 2003, 307:839-845.

5. Watson CS: The Identities of Membrane Steroid Receptors ... and Other Proteins Mediating Nongenomic Steroid Action Boston: Kluwer Academic Publishers; 2003.

6. Shaul PW: Regulation of endothelial nitric oxide synthase: location, location, location. Annu Rev Physiol 2002, 64:749-774.

7. Razandi M, Oh P, Pedram A, Schnitzer J, Levin ER: ERs associate with and regulate the production of caveolin: implications for signaling and cellular actions. Mol Endocrinol 2002 16:100-115.

8. Watson CS, Gametchu B: Membrane-initiated steroid actions and the proteins which mediate them [review]. Proc Soc Exp Biol Med 1999, 220:9-19.

9. Russell KS, Haynes MP, Sinha D, Clerisme E, Bender JR: Human vascular endothelial cells contain membrane binding sites for estradiol, which mediate rapid intracellular signaling. Proc Nat/ Acad Sci USA 2000, 97:5930-5935.

10. Endoh H, Sasaki H, Maruyama K, Takeyama K, Waga I, Shimizu T, Kato S, Kawashima H: Rapid activation of MAP kinase by estrogen in a bone cell line. Biochem Biophys Res Commun 1997, 235:99-102.

11. Watters JJ, Campbell JS, Cunningham MJ, Krebs EG, Dorsa DM: Rapid membrane effects of steroids in neuroblastoma cells: effects of estrogen and mitogen activated protein kinase signalling cascade and C-FOS immediate early gene transcription. Endocrinology 1997, 138:4030-4033.

12. Migliaccio A, Di Domenico M, Castoria G, De Falco A, Bontempo $P$, Nola E, Auricchio F: Tyrosine kinase/P21(RAS)/MAP-kinase pathway activation by estradiol-receptor complex in MCF-7 cells. EMBO J 1996, 15:1292-1300. 
13. Razandi M, Pedram A, Park ST, Levin ER: Proximal events in signaling by plasma membrane estrogen receptors. J Biol Chem 2003, 278:2701-2712.

14. Zhang Z, Maier B, Santen RJ, Song RX: Membrane association of estrogen receptor alpha mediates estrogen effect on MAPK activation. Biochem Biophys Res Commun 2002, 294:926-933.

15. Pappas TC, Gametchu B, Yannariello-Brown J, Collins TJ, Watson $\mathrm{CS}$ : Membrane estrogen receptors in GH3/B6 cells are associated with rapid estrogen-induced release of prolactin. Endocrine 1994, 2:813-822.

16. Pappas TC, Gametchu B, Watson CS: Membrane estrogen receptor-enriched $\mathrm{GH}_{3} / \mathrm{B} 6$ cells have an enhanced nongenomic response to estrogen. Endocrine 1995, 3:743-749.

17. Pappas TC, Gametchu B, Watson CS: Membrane estrogen receptors identified by multiple antibody labeling and impeded-ligand binding. FASEB J 1995, 9:404-410.

18. Norfleet AM, Clarke C, Gametchu B, Watson CS: Antibodies to the estrogen receptor-a modulate prolactin release from rat pituitary tumor cells through plasma membrane estrogen receptors. FASEB J 2000, 14:157-165.

19. English J, Pearson G, Wilsbacher J, Swantek J, Karandikar M, Xu $\mathrm{S}$, Cobb $\mathrm{MH}$ : New insights into the control of MAP kinase pathways. Exp Cell Res 1999, 253:255-270.

20. Gametchu B: Glucocorticoid receptor-like antigen in lymphoma cell membranes: correlation to cell lysis. Science 1987, 236:456-461.

21. Gametchu B, Watson C, Shih C, Dashew B: Studies on the arrangement of glucocorticoid receptors in the plasma membrane of S-49 lymphoma cells. Steroids 1991, 56:411-419.

22. Norfleet AM, Thomas ML, Gametchu B, Watson CS: Estrogen receptor-a detected on the plasma membrane of aldehydefixed $\mathrm{GH}_{3} / \mathrm{B} 6 / \mathrm{F} 10$ rat pituitary tumor cells by enzyme-linked immunocytochemistry. Endocrinology 1999, 140:3805-3814.

23. Campbell $\mathrm{CH}$, Watson CS: A comparison of membrane vs. intracellular estrogen receptor-alpha in GH3/B6 pituitary tumor cells using a quantitative plate immunoassay. Steroids 2001, 66:727-736.

24. Campbell CH, Bulayeva N, Brown DB, Gametchu B, Watson CS: Regulation of the membrane estrogen receptor- $\alpha$ : role of cell density, serum, cell passage number, and estradiol. FASEB J 2002, 16:1917-1927.

25. Song KS, Li SW, Okamoto T, Quilliam LA, Sargiacomo M, Lisanti MP: Co-purification and direct interaction of Ras with caveolin, an integral membrane protein of caveolae microdomains: detergent-free purification of caveolae membranes. J Biol Chem 1996, 271:9690-9697.

26. Bulayeva NN, Gametchu B, Watson CS: Quantitative measurement of estrogen-induced ERK 1 and 2 activation via multiple membrane-initiated signaling pathways. Steroids 2004, 69:181-192.

27. Lottering $M-L$, Haag $M$, Seegers JC: Effects of 17 $\beta$-estradiol metabolites on cell cycle events in MCF-7 cells. Cancer Res 1992, 52:5926-5932.

28. Zivadinovic D, Gametchu B, Watson CS: Membrane estrogen receptor- $\alpha$ levels in MCF-7 breast cancer cells predict CAMP and proliferation responses. Breast Cancer Res 2004, 7:R101-R112.

29. Lobenhofer EK, Marks JR: Estrogen-induced mitogenesis of MCF-7 cells does not require the induction of mitogen-activated protein kinase activity. J Steroid Biochem Mol Biol 2000, 75:11-20

30. Wera S, Hemmings BA: Serine/threonine protein phosphatases. Biochem J 1995, 311:17-29.

31. Boe R, Gjertsen BT, Vintermyr OK, Houge G, Lanotte M, Doskeland SO: The protein phosphatase inhibitor okadaic acid induces morphological-changes typical of apoptosis in mammalian-cells. Exp Cell Res 1991, 195:237-246.

32. Cohen $\mathrm{P}$, Holmes CF, Tsukitani Y: Okadaic acid: a new probe for the study of cellular regulation. Trends Biochem Sci 1990, 15:98-102.

33. Pietras RJ, Szego CM: Specific binding sites for oestrogen at the outer surfaces of isolated endometrial cells. Nature 1977, 265:69-72.

34. Berthois $Y$, Pourreau-Schneider N, Gandilhon P, Mittre H, Tubiana $\mathrm{N}$, Martin PM: Estradiol membrane binding sites on human breast cancer cell lines. Use of a fluorescent estradiol conju- gate to demonstrate plasma membrane binding systems. $J$ Steroid Biochem 1986, 25:963-972.

35. Germain PS, Metezeau P, Tiefenauer LX, Kiefer H, Ratinaud MH, Habrioux G: Use of a biotinyl-estradiol derivative to demonstrate estradiol-membrane binding sites on adherent human breast cancer MCF-7 cells. Anticancer Res 1993, 13:2347-2354

36. Sager R, Sheng S, Anisowicz A, Sotiropoulou G, Zou Z, Stenman G, Swisshelm K, Chen Z, Hendrix MJ, Pemberton P: RNA genetics of breast cancer: Maspin as paradigm. Cold Spring Harb Symp Quant Biol 1994, LIX:537-546.

37. Engelman JA, Zhang X, Galbiati F, Volonte D, Sotgia F, Pestell RG, Minetti C, Scherer PE, Okamoto T, Lisanti MP: Molecular genetics of the caveolin gene family: implications for human cancers, diabetes, Alzheimer disease, and muscular dystrophy. Am J Hum Genet 1998, 63:1578-1587.

38. Lavie $\mathrm{Y}$, Fiucci G, Liscovitch M: Up-regulation of caveolae and caveolar constituents in multidrug-resistant cancer cells. $J \mathrm{Bio}$ Chem 1998, 273:32380-32383.

39. Scherer PE, Lewis RY, Volonte D, Engelman JA, Galbiati F, Couet J, Kohtz DS, van Donselaar E, Peters P, Lisanti MP: Cell-type and tissue-specific expression of caveolin-2. Caveolins 1 and $2 \mathrm{co}-$ localize and form a stable hetero-oligomeric complex in vivo. J Biol Chem 1997, 272:29337-29346.

40. Jensen J, Kitlen JW, Briand P, Labrie F, Lykkesfeldt AE: Effect of antiestrogens and aromatase inhibitor on basal growth of the human breast cancer cell line MCF-7 in serum-free medium. $J$ Steroid Biochem Mol Biol 2003, 84:469-478.

41. Santen R, Jeng MH, Wang JP, Song R, Masamura S, McPherson R, Santner S, Yue W, Shim WS: Adaptive hypersensitivity to estradiol: potential mechanism for secondary hormonal responses in breast cancer patients. J Steroid Biochem Mol Biol 2001, 79:115-125

42. Poola I, Koduri S, Chatra S, Clarke R: Identification of twenty alternatively spliced estrogen receptor alpha mRNAs in breas cancer cell lines and tumors using splice targeted primer approach. J Steroid Biochem Mol Biol 2000, 72:249-258.

43. Fasco MJ, Keyomarsi K, Arcaro KF, Gierthy JF: Expression of an estrogen receptor alpha variant protein in cell lines and tumors. Mol Cell Endocrinol 2000, 162:167-180.

44. Li L, Haynes MP, Bender JR: Plasma membrane localization and function of the estrogen receptor alpha variant (ER46) in human endothelial cells. Proc Natl Acad Sci USA 2003, 100:4807-4812.

45. Flouriot G, Brand H, Denger S, Metivier R, Kos M, Reid G, Sonntag-Buck V, Gannon F: Identification of a new isoform of the human estrogen receptor-alpha (hER-alpha) that is encoded by distinct transcripts and that is able to repress hER-alpha activation function 1. EMBO J 2000, 19:4688-4700.

46. Marquez DC, Pietras RJ: Membrane-associated binding sites for estrogen contribute to growth regulation of human breast cancer cells. Oncogene 2001, 20:5420-5430.

47. Bulayeva N, Gametchu B, Watson CS: Quantitative measurement of MAP kinase activation by estrogens via multiple signaling pathways. Steroids 2004 in press.

48. Filardo EJ, Quinn JA, Bland KI, Frackelton AR: Estrogen-induced activation of Erk-1 and Erk-2 requires the G protein-coupled receptor homolog, GPR30, and occurs via trans-activation of the epidermal growth factor receptor through release of HBEGF. Mol Endocrinol 2000, 14:1649-1660.

49. Ahola TM, Manninen T, Alkio N, Ylikomi T: G protein-coupled receptor $\mathbf{3 0}$ is critical for a progestin-induced growth inhibition in MCF-7 breast cancer cells. Endocrinology 2002, 143:3376-3384.

50. Ahola TM, Purmonen S, Pennanen $P$, Zhuang $Y H$, Tuohimaa $P$ Ylikomi T: Progestin upregulates G-protein-coupled receptor 30 in breast cancer cells. Eur J Biochem 2002, 269:2485-2490.

51. Chang FM, Steelman LS, Shelton JG, Lee JT, Navolanic PM, Blalock WL, Franklin R, McCubrey JA: Regulation of cell cycle progression and apoptosis by the Ras/Raf/MEK/ERK pathway. Int $J$ Oncol 2003, 22:469-480.

52. Pink JJ, Jordan VC: Models of estrogen receptor regulation by estrogens and antiestrogens in breast cancer cell lines. Cancer Res 1996, 56:2321-2330.

53. Dudley MW, Sheeler CQ, Wang H, Khan S: Activation of the human estrogen receptor by the antiestrogens $\mathrm{ICI} 182,780$ and tamoxifen in yeast genetic systems: implications for their 
mechanism of action. Proc Natl Acad Sci USA 2000, 97:3696-3701.

54. Aronica SM, Kraus WL, Katzenellenbogen BS: Estrogen action via the CAMP signaling pathway: stimulation of adenylate cyclase and cAMP-regulated gene transcription. Proc Natl Acad Sci USA 1994, 91:8517-8521.

55. Kiefer T, Ram PT, Yuan L, Hill SM: Melatonin inhibits estrogen receptor transactivation and CAMP levels in breast cancer cells. Breast Cancer Res Treat 2002, 71:37-45.

56. Keshamouni VG, Mattingly RR, Reddy KB: Mechanism of 17beta-estradiol-induced Erk1/2 activation in breast cancer cells. A role for HER2 AND PKC-delta. J Biol Chem 2002, 277:22558-22565.

57. Improta-Brears $\mathrm{T}$, Whorton AR, Codazzi F, York JD, Meyer T, McDonnell DP: Estrogen-induced activation of mitogen-activated protein kinase requires mobilization of intracellular calcium. Proc Natl Acad Sci USA 1999, 96:4686-4691.

58. Varma $\mathrm{H}$, Conrad SE: Antiestrogen ICl 182,780 decreases proliferation of insulin-like growth factor I (IGF-I)-treated MCF-7 cells without inhibiting IGF-I signaling. Cancer Res 2002, 62:3985-3991.

59. Yue W, Wang JP, Conaway M, Masamura S, Li Y, Santen RJ: Activation of the MAPK pathway enhances sensitivity of MCF-7 breast cancer cells to the mitogenic effect of estradiol. Endocrinology 2002, 143:3221-3229.

60. Wong JK, Le HH, Zsarnovszky A, Belcher SM: Estrogens and ICl182,780 (Faslodex) modulate mitosis and cell death in immature cerebellar neurons via rapid activation of $\mathrm{p} 44 / \mathrm{p} 42$ mitogen-activated protein kinase. J Neurosci 2003, 23:4984-4995.

61. Watson CS, Pappas TC, Gametchu B: The other estrogen receptor in the plasma membrane: implications for the actions of environmental estrogens. Environ Health Perspect 1995, 103(Suppl 7):41-50.

62. Robertson JA, Zhang $Y$, Ing $\mathrm{NH}$ : ICl 182,780 acts as a partial agonist and antagonist of estradiol effects in specific cells of the sheep uterus. J Steroid Biochem Mol Biol 2001, 77:281-287

63. Manole D, Schildknecht B, Gosnell B, Adams E, Derwahl M: Estrogen promotes growth of human thyroid tumor cells by different molecular mechanisms. J Clin Endocrinol Metab 2001, 86:1072-1077

64. Cohen P: The regulation of protein function by multisite phosphorylation: a 25 year update. Trends Biochem Sci 2000, 25:596-601.

65. Carr $\mathrm{Bl}$, Wang Z, Kar S: K vitamins, PTP antagonism, and cell growth arrest. J Cell Physiol 2002, 193:263-274.

66. Pawlowski M, Ragab A, Rosa JP, Bryckaert M: Selective dephosphorylation of the threonine(183) residue of ERK2 upon (alpha)llb(beta)3 engagement in platelets. FEBS Lett 2002, 521:145-151.

67. Camps M, Nichols A, Arkinstall S: Dual specificity phosphatases: a gene family for control of MAP kinase function. FASEB J 2000, 14:6-16.

68. Zhang ZY, Zhou B, Xie L: Modulation of protein kinase signaling by protein phosphatases and inhibitors. Pharmacol Ther 2002, 93:307-317. 